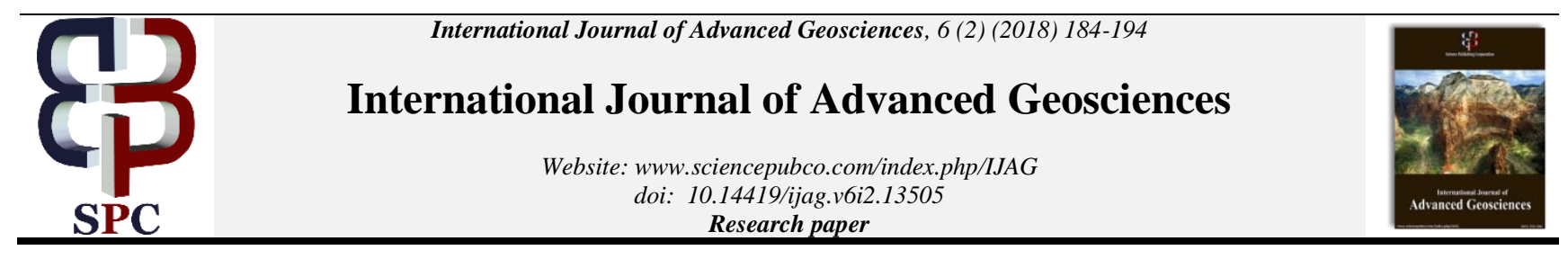

\title{
Geochemical and geotechnical characterization of soils developed on volcanic rocks in the Bamenda mountain (Cameroon volcanic line)
}

\author{
Kagou Dongmo A ${ }^{1 *}$, Guedjeo C. S ${ }^{1,2}$, Azinwi Tamfuh P. ${ }^{3}$, Wotchoko $P^{2}$, Chenyi M. L ${ }^{1}$, Aziwo B.T ${ }^{1}$, \\ Kamgang K. $\mathbf{V}^{1}$ \\ ${ }^{1}$ Department of Earth Sciences, Faculty of Sciences, University of Dschang, PO Box 67, Dschang, Cameroon \\ ${ }^{2}$ Department of Geology, Higher Teacher's Training College, University of Bamenda, P.O. Box 39 Bambili, Cameroon \\ ${ }^{3}$ Department of soil science, Faculty of Agronomy and Agricultural Sciences, P.O Box 222, Dschang, Cameroon \\ *Corresponding author E-mail: guedjeochristian@yahoo.fr
}

\begin{abstract}
The weathering mechanism of rocks exposed to the same conditions on the Bamenda Mountain is not well understood. The aim of this study is to characterize basalt, trachyte and rhyolite and their products on the geochemical and geotechnical aspect. Here three wells were hand-dug on soils developed on basalt, trachyte and rhyolite and studied in details. The results showed high Ki values (0.34-6.57) indicating that $\mathrm{SiO}_{2}$ is more leached in the soils developed on basalt than those on trachyte and rhyolite. Also, high CIA (72.62-97.8) and CIW (72.76-98.8) values are typical of an advanced to extreme chemical weathering in this environment, with rhyolite and trachyte being more weathered than basalts. Soils formed on basalt have ICV $>1$ characteristic of young and immature soils, while for trachyte and rhyolite $\mathrm{ICV}=0.3-0.5$ indicating intense chemical weathering. $\mathrm{Al}\left(\mathrm{EF}_{\mathrm{Al}}=1.5\right)$ and $\mathrm{Fe}\left(\mathrm{EF}_{\mathrm{Fe}}=1.3\right)$ are enriched in the soils while $\mathrm{SiO}_{2}, \mathrm{Na}, \mathrm{K}, \mathrm{Ca}$ and $\mathrm{Mg}$ are instead depleted increasingly from base to the top of the profile. Geotechnically, these soils are predominantly silty, well graded, less plastic $(\mathrm{LI}<0)$, plastic $(\mathrm{CI}>1)$ to moderately plastic $(\mathrm{PI}=7.2-15.8)$. The soils developed on rhyolite have high clay content $\mathrm{MBV}=3.3-8$, but low water content $(10-42 \%)$. Texturally, these soil are silty loam, loam to sandy loam soils. Soil strength is low: cohesion $(<0.5$ bar $)$, angle of internal friction $\left(10-43^{\circ}\right)$, with shallow landslides $(1-2 \mathrm{~m})$ more likely to occur on trachyte and on rhyolites.
\end{abstract}

Keywords: Geochemistry; Geotechnics; volcanic soils, Rhyolite; Trachyte; Bamenda Mountain.

\section{Introduction}

The Bamenda Mountains $(2621 \mathrm{~m})$ is a stratovolcano which is part of the Western Cameroon Highland (WCH) along the Cameroon Volcanic Line (CVL), a major structure in Central Africa. Volcanic activity on this Mountain emplaced rocks which are predominantly; basalt, trachyte and rhyolite (Kamgang et al. 2010; 2007). These rocks have since been exposed to climatic factors such as rainfall and varying temperatures and tend to undergo mineralogical transformations. Situated in the tropics, this Mountain experiences intense chemical weathering. During alteration processes, some elements may be enriched or depleted in the saprolite, platy nodules and soil matrices. The geochemical nature of a soil affects its geotechnical properties given that it conditions the structure and texture of the soils. The study of weathering on rocks in tropical zones has also been evaluated in some areas in Cameroon (Veronica et al. 2013; Ndjigui et al. 2013; 2008; Kouayep et al. 2012; Tematio et al. 2012; Bayiga et al. 2011; Tsopjio et al. 2011). This paper aims to explain the geochemical transformations during the weathering of basalt, trachyte and rhyolite and the geotechnical behaviour of the resultant soils. Thus, three soil profiles were studied on: basalt, trachyte and rhyolite to determine (1) the degree of weathering using different geochemical indices, (2) the relative mobility of the major, trace and rare earth elements (3) the geotechnical properties of soils and influence on slope failure.

\section{Methods}

Three wells were hand dug to expose the soil profile developed on basalt, trachyte and rhyolite denoted (PB, PT and PR profiles respectively). The nature of limits, humidity, main constituents, structure, form, size, hardness, relationship between the grains and aggregates, porosity, pedologic features, structural stability of the aggregates and rooting were described. Soil samples were extracted from these profiles in triplets and air dried. Soil and rock pulps were prepared in the BOCOM group laboratory in Douala Cameroon and were submitted to the ALS Lab Johannesberg, Guateng, South Africa. Geochemical analyses were performed on the pulps using the following procedures; whole rock package ICP-AES, Loss on Ignition was done at 1000C OA-GRA05 code, Lithium Borate Fusion ICP-MS (ME-MS81) and Total calculation for ICP06 (TOT-ICP06).

From major elements data, the weathering indices of the soil samples were determined such as: chemical index of weathering $(\mathrm{CIW})=\left[\mathrm{Al}_{2} \mathrm{O}_{3} /\left(\mathrm{Al}_{2} \mathrm{O}+\mathrm{CaO}^{*}+\mathrm{N}_{2} \mathrm{O}\right)\right] \mathrm{x} 100$ (Harnois 1988), chemical index of alteration $(\mathrm{CIA})=\left[\mathrm{Al}_{2} \mathrm{O}_{3} /\left(\mathrm{Al}_{2} \mathrm{O}_{3}+\mathrm{CaO} *\right.\right.$ 
$\left.\left.+\mathrm{Na}_{2} \mathrm{O}+\mathrm{K}_{2} \mathrm{O}\right)\right]$ x100 where $\mathrm{CaO}^{*}$ is the content of calcium oxide in fresh rock (Nestbitt and Young 1989), the molar ratio (Ki) = $\mathrm{SiO}_{2} / \mathrm{Al}_{2} \mathrm{O}_{3}$ (Ruxton 1968) and the bases $/ \mathrm{R}_{2} \mathrm{O}_{3}=$ $[(\mathrm{MgO}+\mathrm{CaO}+\mathrm{NaO}) /(\mathrm{Al})] \times 100$ (Birkeland 1999). Chemical mass balance between soils phases were estimated from the calculations of enrichment/depletion factors determined using $\mathrm{Ti}$ as immobile element. This was estimated by the ratio between the content of an element in a soil phase and that of fresh rock according to the relation $\mathrm{EF}(\mathrm{X})=(\mathrm{Xi} / \mathrm{Ri}) /(\mathrm{Xs} / \mathrm{Rs})(\mathrm{Rahn}$ and Mc Cafrfrey 1979) , where $\mathrm{Xi}$ and $\mathrm{Ri}$ are the concentrations of the element of interest and that of a reference element (Ti) in a given soil phase where $\mathrm{Xs}$ and Rs are the concentrations of the same elements in fresh rock. Index of compositional variability (ICV) = $\left.\left(\mathrm{Fe}_{2} \mathrm{O}_{3}+\mathrm{K}_{2} \mathrm{O}+\mathrm{NaO}+\mathrm{CaO}+\mathrm{MgO}+\mathrm{MnO}+\mathrm{TiO}\right) / \mathrm{AlO}_{3}\right)$ estimates the degree of chemical weathering (Cox et al. 1995). The REE concentrations were normalized relative to CI Chondrite (Boynton 1984). The $(\mathrm{La} / \mathrm{Yb})$ ratios were calculated to indicate the degree of LREE to HREE fractionation, while the $(\mathrm{La} / \mathrm{Sm}) \mathrm{N}$ measures the degree of LREE to MREE fractionation.

Geotechnical analyses were performed at the MIPROMALO and LABOGENIE Laboratories, Yaoundé, Cameroon. Grain size distribution analysis was done following the NF P 94-056 French norm. Methylene blue test was performed using the NF P94-068 norm. Atterberg limits were determined by varying the water content within the soils following the NF P 94-051 norm. Liquid limit was determined using the Casagrande's device. The water content was determined by comparing the weight of the wet sample to that of the oven-dried sample. The plastic limit was determined by rolling the soil into a 3 to $10 \mathrm{~mm}$, noting where it starts breaking. The consistency limit was the ratio of the difference between the liquid limit and the water content on the plastic index. Bulk density was determined using the hydrostatic scale applying the Archimedes principle. Particle density was determined with the help of a pycometer following the principle of Robitaille and Tremblay
(1997). Angle of internal friction and cohesion were determined using the consolidated undrained triaxial test.

\section{Results}

\subsection{Soil morphology and structure}

The morphologic characteristics of the studied profiles are presented in table 1 . The soil profile developed on trachyte (PT) at an altitude of $1,965 \mathrm{~m}$ at Santa, on a slope of $20^{\circ}$. The vegetation type where the well was dug is Sudan savannah, with cattle rearing as the main activity. This profile has horizons $\mathrm{O}, \mathrm{A}, \mathrm{B}$ and $\mathrm{C}$. The $\mathrm{O}(0-25 \mathrm{~cm})$ horizon is gray in colour $(\mathrm{N} 6 / 6)$, highly rooted, granular, moderate grade, and medium grain sizes with a loam texture. Its contact with the underlying horizon is diffuse. A (25$75 \mathrm{~cm}$ Horizon) is reddish gray in colour $(10 \mathrm{R} 6 / 6 / 1)$ with white (N8/8/1) patches, roots are absent here, the grade of the soil here is weak, the soil is granular, the grain sizes are fine grained, the texture is loamy, its contact with the lower horizon is diffuse. The B $(75-160 \mathrm{~cm})$ Horizon is yellow in colour $(10 \mathrm{YR} 8 / 8)$, within this horizon are very dark brown (10YR2/2) and light red (10R7/8) particles disseminated within the horizon, the grade of the soil is moderate with well-formed distinct aggregates. The grains size is fine, with and blocky in shape. The texture is loam and clay. Its transition to the next horizon is distinct. However, it has some patches of isalterite white colour $(2.5 \mathrm{Y} 8 / 1)$ material. Horizon $\mathrm{C}$ $(160-500 \mathrm{~cm})$ is the isalterite layer, with a white colour $(2.5 \mathrm{Y} 8 / 1)$ to very pale brown $(10 \mathrm{YR} 8 / 4)$ with relics of the parent rock still observed. The grade is strong with shape of aggregates being blocky, its grain sizes are medium to fine grain, and it has a loamy sand texture (Fig.1A). In this profile four soil samples were collected for analysis: TA1, TB1, TC, and TC2 as well as the parent rock.

Table 1: Characteristic of Soil Samples from Developed Pedon on the Bamenda Mountain

\begin{tabular}{|c|c|c|c|c|c|c|c|}
\hline Pedon & & Horizon & sample & Sampling depth (cm) & colour & Textural class & structure \\
\hline \multirow{3}{*}{ PR } & \multirow{3}{*}{ 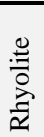 } & \multirow[b]{2}{*}{ A } & RA1 & 20 & 7.5YR6/3 (brown) & Loam & Strong aggregates \\
\hline & & & RA2 & 70 & $7.5 \mathrm{Y} / 6 / 2$ (pinkish gray) & Loam & Strong aggregates \\
\hline & & $\mathrm{BC}$ & $\mathrm{RBC} 1$ & 150 & 10YR/7/8 (yellow) & Silty & Strong aggregates \\
\hline \multirow{4}{*}{ PT } & \multirow{4}{*}{ 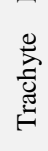 } & A & TA1 & 50 & 10R6/1 (reddish gray) & loam & Regular, moderate grade \\
\hline & & $\mathrm{B}$ & TB1 & 120 & 10YR/8/8 (yellow) & loam & Regular, weak grade \\
\hline & & & $\mathrm{TC} 1$ & 300 & 7.5YR/8/6, (reddish yellow) & Loamy sand & Strong grade \\
\hline & & C & $\mathrm{TC} 2$ & 315 & $10 \mathrm{YR} 2 / 2$ (very dark brown) & Loamy sand & Strong grade, blocky \\
\hline \multirow{3}{*}{ PB } & \multirow{3}{*}{ 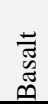 } & A & BA1 & 60 & 5YR5/6 (yellowish red) & Silty loam & Weak aggregate \\
\hline & & $\mathrm{B}$ & BB1 & 170 & $2.5 \mathrm{Y} 8 / 8$ (yellow) & Sandy loam & No agrregates \\
\hline & & $\mathrm{C}$ & $\mathrm{BC} 1$ & 200 & $2.5 \mathrm{Y} 7 / 3$ (pale yellow) & Sandy loam & Strong grade \\
\hline
\end{tabular}

The PB profile developed on basalt at an altitude of $1,565 \mathrm{~m}$ at Awing, on a slope of $1^{\circ}$. The vegetation where the well was dug is anthropogenized, with some fruit trees and cash crops. This profile was $3 \mathrm{~m}$ deep presenting a complete profile with Horizons O, A, B and C. $\mathrm{O}(0-20 \mathrm{~cm})$ Horizon, is the organic layer and is characterized by the presence of plant remains with dark gray colour (5YR4/1). The grade of the soil here is weak, with poorly formed aggregates. This layer has a high concentration of roots its limit with the underlying horizon is distinct. A $(20-140 \mathrm{~cm})$ Horizon has a yellowish red colour (5YR5/6) and is rooted. Its grade is strong with distinct cloth of aggregates observed. The shape of the aggregates is granular and the grain sizes are medium to fine. The soil has a silty loam texture; its limit with the next horizon is distinct. B (140-180cm) Horizon is yellowish in colour (2.5Y8/8), with some dark inclusions (2.5Y/2.5/1). Roots are completely absent within this layer. The grade of the soil here has no aggregates, and is massive. The shape of the grains is massive, with medium grain sizes. Its limit is distinct with the next horizon and it has a sandy loam texture. The C $(180-300 \mathrm{~cm})$ Horizon is the isalterite layer, with relics of parent rock observed. It presents varied colours from red $(2.5 \mathrm{YR} / 5 / 8)$, yellow $(2.5 \mathrm{Y} 8 / 8)$ to gray $(2.5 \mathrm{Y} / 6 / 1)$ and the grain sizes are medium grain. The grade is strong with aggregates of parent rock within this profile. In this profile, three soil samples were collected for analyses which were; BA1, BB1 and BC1 as well as the parent rock (Fig.1B).

The PR profile developed on rhyolite at an altitude of 1,665.m at Awing on a slope of $15^{\circ}$ the profile is complete made up of horizons; $\mathrm{O}, \mathrm{A}, \mathrm{B}$ and $\mathrm{C}$. The vegetation in the area is the savanah savanah. The horizon $\mathrm{O}(0-10 \mathrm{~cm})$, light brownish gray in colour $(2.5 \mathrm{Y} 6 / 2)$ and rooted. It is granular, with weak grade of aggregates. The gain sizes are fine grained, with a heavy loam texture, its limit with the next horizon is indistinct. Horizon A (10$90 \mathrm{~cm})$ is light brwon in colour $(7.5 \mathrm{YR} 6 / 3)$ and is not rooted, the grade of aggregation is weak, its limits are indsitinct. The BC horizon $(90-300 \mathrm{~cm})$ is a mixture of the $\mathrm{B}$ and $\mathrm{C}$ horizon with accumulation of clayey materials and weathered products still beraring structures of the parent rock; this horizon is light reddish brown $(5 \mathrm{YR} 5 / 8)$ to whitish $(2.5 \mathrm{Y} 8 / 1)$ in colour with lenses (along joints in parent material) of yellow (10YR/7/8) accumulations. It is has a strong grade as the soils adhere weakly to one another when disturbed, the shape of the aggregates are prismatic. The texture is clayey, with very fine grains. The structures of the parent materials are well preserved. It also has strong grade of aggregates and shape of grains is primatic. In this profile, four soil samples 
were collected namely; RA1, RA2, RBC1 and RBC2 as well as the parent rock (Fig.1C).

(A)

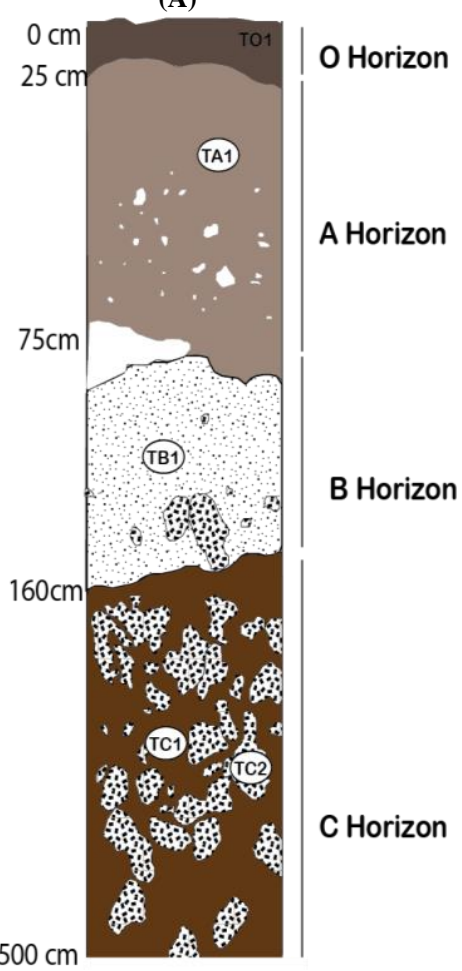

(B)

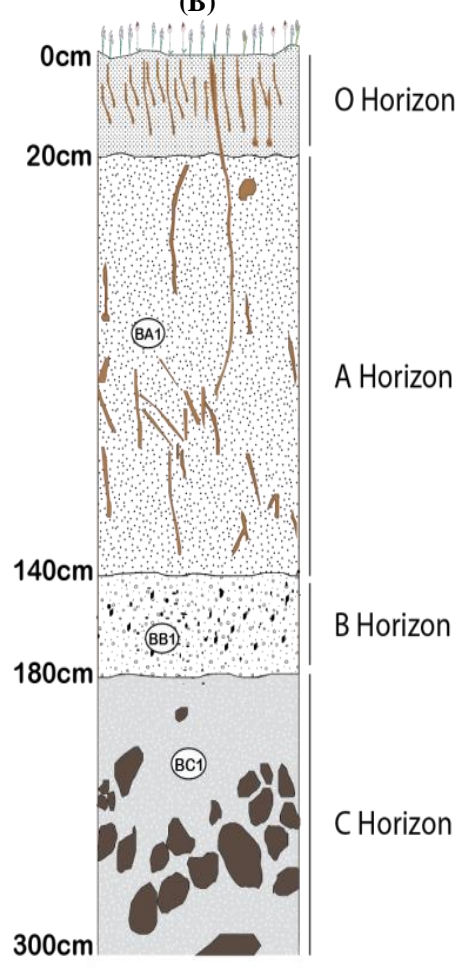

(C)

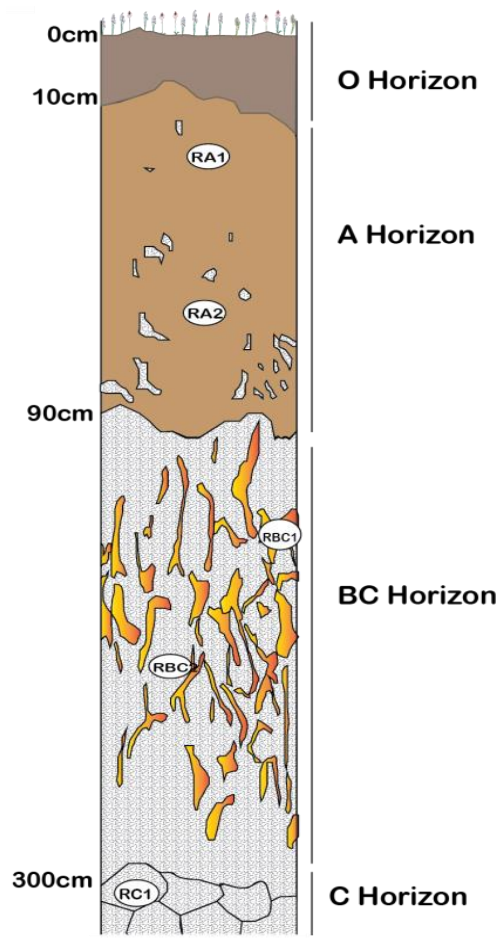

Fig. 1: Soil Profiles from the Bamenda Mountain (A) PT Profile (B) PB Profile (C) PR Profile.

\subsection{Soil geochemistry}

\subsubsection{Levels and distribution of major elements}

The concentrations of the analyzed major oxides are presented in table 2. Within all the studied profiles, the LOI of the soil samples are significantly high $(11.25-20.7 \%)$ relative to the parent rocks (0.87-2.95) with soil samples developed on basalt presenting the highest values. The concentration of $\mathrm{SiO}_{2}$ reduces from the parent rock to the soils in all the soil profiles. In soils on basalt, $\mathrm{SiO}_{2}$ content increases from $\mathrm{BC} 1$ phase towards the surface, with values ranging from $(9.57-17.4 \%)$ relative to the other soil profiles. In soils developed on rhyolite, $\mathrm{SiO}_{2}$ is less leached; it reduces from the rock to the RBC phases before increasing in the RA phases with values of 52.3-55.6\%. In soils developed on trachyte, $\mathrm{SiO}_{2}$ content reduces from the parent rock to the TB1 phase $(38.9 \%)$, before increasing in the TA1 phase close to the surface $(49.5 \%)$. The concentration of $\mathrm{SiO}_{2}$ remains high in soils on rhyolite and trachyte relative to those on basalt. The concentration of $\mathrm{Al}_{2} \mathrm{O}_{3}$ and $\mathrm{Fe}_{2} \mathrm{O}_{3}$ are the highest in all the soil profiles relative to the other major elements and increase from the parent rock to the soil phases, with $\mathrm{Al}_{2} \mathrm{O}_{3}$ more abundant than $\mathrm{Fe}_{2} \mathrm{O}_{3}$ in the soil. The concentration of these elements is highest in soils developed on basalt, with values of $\mathrm{Al}_{2} \mathrm{O}_{3}$ and $\mathrm{Fe}_{2} \mathrm{O}_{3}$ of $30.4 \%$ and $29.7 \%$ respectively. In soils on rhyolites, $\mathrm{Al}_{2} \mathrm{O}_{3}$ increases from the parent rock up to the $\mathrm{RBC} 1$ phase $(30.3 \%)$ before reducing in the RA phases $(26.2 \%)$. In soils on trachyte, $\mathrm{Al}_{2} \mathrm{O}_{3}$ increases from parent rock to the TC2 phase $(25.5 \%)$ before reducing in the TB1 phase $(15 \%)$ and increase again TA1 phase $(25.5 \%)$ close to the surface. The concentrations of $\mathrm{Fe}_{2} \mathrm{O}_{3}$ is highest in soils on basalt (29.7\%) relative to those on rhyolite and trachyte $(7.7$ and $9.26 \%)$ respectively. However, in the TB1 phase the concentration of $\mathrm{Fe}_{2} \mathrm{O}_{3}$ increases abruptly (23.9) and reduces again towards the TA1 phase $(7.18 \%)$ close to the surface

Table 2: Major Elements Oxides and Weathering Indices of the Bamenda Mountain

\begin{tabular}{|c|c|c|c|c|c|c|c|c|c|c|c|c|c|c|}
\hline \multirow[b]{3}{*}{ Elements } & \multicolumn{4}{|c|}{ Profile PB } & \multicolumn{5}{|c|}{ Profile PR } & \multicolumn{5}{|c|}{ Profile PT } \\
\hline & \multirow[b]{2}{*}{ B01 } & \multirow{2}{*}{$\begin{array}{l}\text { Horizon } \\
\text { BC } \\
\text { BC1 }\end{array}$} & \multirow{2}{*}{$\begin{array}{l}\text { Horizon } \\
\text { B } \\
\text { BB1 }\end{array}$} & \multirow{2}{*}{$\begin{array}{l}\text { Horizon } \\
\text { A } \\
\text { BA1 }\end{array}$} & \multirow[b]{2}{*}{ R01 } & \multicolumn{2}{|c|}{ Horizon BC } & \multicolumn{2}{|c|}{ Horizon A } & \multirow[b]{2}{*}{ SAK } & \multicolumn{2}{|c|}{ Horizon C } & \multirow{2}{*}{$\begin{array}{l}\text { Horizon } \\
\text { B } \\
\text { TB1 }\end{array}$} & \multirow{2}{*}{$\begin{array}{l}\text { Horizon } \\
\text { A } \\
\text { TA1 }\end{array}$} \\
\hline & & & & & & $\begin{array}{l}\mathrm{RBC} \\
2\end{array}$ & $\begin{array}{l}\text { RBC } \\
1\end{array}$ & RA2 & RA1 & & $\mathrm{TC} 2$ & $\mathrm{TC} 1$ & & \\
\hline $\mathrm{SiO}_{2}$ & 41.7 & 9.57 & 16.2 & 17.4 & 69.3 & 55.6 & 47.4 & 55.8 & 52.3 & 63.4 & 48.7 & 50.4 & 38.9 & 49.5 \\
\hline $\mathrm{Al}_{2} \mathrm{O}_{3}$ & $\begin{array}{l}13.7 \\
5\end{array}$ & 28.3 & 30.3 & 30.4 & 15.2 & 26 & 30.3 & 26.2 & 27.8 & 15.2 & 25.5 & 22.8 & 19 & 25 \\
\hline $\mathrm{Fe}_{2} \mathrm{O}_{3}$ & 14.4 & 29.7 & 27.1 & 23.7 & 4.6 & 5.58 & 7.36 & 6.29 & 7.7 & 5.92 & 7.54 & 9.26 & 23.9 & 7.18 \\
\hline $\mathrm{MgO}$ & 7.87 & 0.54 & 0.28 & 0.29 & 0.02 & 0.01 & 0.02 & 0.01 & 0.02 & 0.22 & 0.18 & 0.08 & 0.07 & 0.1 \\
\hline $\mathrm{Na}_{2} \mathrm{O}$ & 2.25 & 0.01 & 0.01 & 0.02 & 4.75 & 0.02 & 0.01 & 0.02 & 0.03 & 5.63 & 0.98 & 1.03 & 0.82 & 0.82 \\
\hline $\mathrm{K}_{2} \mathrm{O}$ & 1.37 & 0.06 & 0.13 & 0.17 & 5.81 & 0.42 & 0.57 & 0.32 & 0.28 & 4.96 & 0.78 & 0.78 & 0.62 & 0.64 \\
\hline $\mathrm{TiO}_{2}$ & 4 & 9.88 & 5.77 & 6.05 & 0.21 & 0.46 & 0.52 & 0.46 & 0.44 & 0.45 & 1.27 & 1.15 & 1.24 & 1.21 \\
\hline $\mathrm{MnO}$ & 0.28 & 0.28 & 0.36 & 0.14 & 0.01 & 0.03 & 0.14 & 0.08 & 0.06 & 0.19 & 0.02 & 0.68 & 0.11 & 0.19 \\
\hline $\mathrm{P}_{2} \mathrm{O}_{5}$ & 0.65 & 0.97 & 0.19 & 0.26 & 0.02 & 0.03 & 0.03 & 0.03 & 0.02 & 0.09 & 0.15 & 0.1 & 0.21 & 0.13 \\
\hline LOI & 2.95 & 19.5 & 19.4 & 20.7 & 0.87 & 11.25 & 13.7 & $\begin{array}{l}11.5 \\
5\end{array}$ & $\begin{array}{l}12.4 \\
5\end{array}$ & 2.25 & 15.75 & 13.6 & 14.5 & 14.8 \\
\hline
\end{tabular}




\begin{tabular}{|c|c|c|c|c|c|c|c|c|c|c|c|c|c|c|}
\hline & 1 & & & & 2 & & & 8 & 1 & 1 & 3 & & & \\
\hline $\begin{array}{l}\mathrm{SiO}_{2} / \mathrm{Al}_{2} \mathrm{O} \\
3\end{array}$ & 3.03 & 0.34 & 0.53 & 0.57 & 4.56 & 2.14 & 1.56 & 2.13 & 1.88 & 4.17 & 1.91 & 2.21 & 2.05 & 1.98 \\
\hline $\begin{array}{l}\mathrm{Fe}_{2} \mathrm{O}_{3} / \mathrm{K}_{2} \\
\mathrm{O}\end{array}$ & $\begin{array}{l}10.5 \\
1\end{array}$ & 495.00 & 208.46 & 139.41 & 0.79 & 13.29 & 12.91 & $\begin{array}{l}19.6 \\
6\end{array}$ & $\begin{array}{l}27.5 \\
0\end{array}$ & 1.19 & 9.67 & $\begin{array}{l}11.8 \\
7\end{array}$ & 38.55 & 11.22 \\
\hline TRB & $\begin{array}{l}22.0 \\
9\end{array}$ & 0.62 & 0.45 & 0.53 & $\begin{array}{l}10.9 \\
3\end{array}$ & 0.47 & 0.61 & 0.37 & 0.34 & $\begin{array}{l}12.2 \\
2\end{array}$ & 2.09 & 1.99 & 1.53 & 1.59 \\
\hline $\begin{array}{l}\mathrm{Ba}- \\
\text { ses } / \mathrm{R}_{2} \mathrm{O}_{3}\end{array}$ & $\begin{array}{l}68.7 \\
1\end{array}$ & 0.91 & 0.71 & 0.88 & $\begin{array}{l}54.6 \\
2\end{array}$ & 1.47 & 1.60 & 1.12 & 0.95 & $\begin{array}{l}56.6 \\
5\end{array}$ & 6.09 & 5.99 & 3.47 & 4.76 \\
\hline CIW & 52 & 72.73 & 74.07 & 74.11 & $\begin{array}{l}74.8 \\
8\end{array}$ & 98.60 & 98.83 & $\begin{array}{l}98.6 \\
1\end{array}$ & $\begin{array}{l}98.6 \\
5\end{array}$ & $\begin{array}{l}68.3 \\
5\end{array}$ & 91.43 & $\begin{array}{l}90.3 \\
3\end{array}$ & 89.50 & 91.81 \\
\hline CIA & & 72.62 & 73.83 & 73.80 & $\begin{array}{l}41.8 \\
0\end{array}$ & 97.05 & 97.02 & $\begin{array}{l}97.4 \\
3\end{array}$ & $\begin{array}{l}97.6 \\
8\end{array}$ & $\begin{array}{l}58.1 \\
5\end{array}$ & 88.94 & $\begin{array}{l}87.6 \\
2\end{array}$ & 86.96 & 89.70 \\
\hline ICV & 2.97 & 1.43 & 1.11 & 1.00 & 1.04 & 0.25 & 0.28 & 0.27 & 0.31 & 1.24 & 0.43 & 0.57 & 1.41 & 0.41 \\
\hline $\mathrm{S}$ & 1.48 & 0.17 & 0.28 & 0.32 & 3.50 & 1.76 & 1.26 & 1.72 & 1.47 & 3.00 & 1.47 & 1.57 & 0.91 & 1.54 \\
\hline
\end{tabular}

The concentrations of $\mathrm{CaO}, \mathrm{K}_{2} \mathrm{O}, \mathrm{Na}_{2} \mathrm{O}$ and $\mathrm{MgO}$ are lowest in all the soil phases relative to their parent rocks. In soils on basalt, these alkaline and alkali-earth elements concentrations drop from the rocks to the soil phases $\mathrm{CaO}(10.6-0.1 \%), \mathrm{MgO}(7.87-0.28 \%)$, $\mathrm{Na}_{2} \mathrm{O}(2.25-0.01 \%)$ and $\mathrm{K}_{2} \mathrm{O}(1.17-0.06 \%)$. In soils on rhyolite and trachyte, the concentrations of $\mathrm{CaO}(0.35 \%)$ and $\mathrm{MgO}$ $(0.02 \%)$ are relatively low and are completely removed in the soils, while $\mathrm{K}_{2} \mathrm{O}$ and $\mathrm{Na}_{2} \mathrm{O}$ are relatively higher in these profiles and also are depleted in the soils as we move towards the surface.

The behaviour of $\mathrm{TiO}_{2}, \mathrm{MnO}$ and $\mathrm{P}_{2} \mathrm{O}_{5}$ are similar. In soils on basalts, the concentration of $\mathrm{TiO}_{2}$ increases from the parent rock in the $\mathrm{BC} 1$ phase $(4-9.88 \%)$ before dropping as we move up the profile. $\mathrm{TiO}_{2}$ concentration in soils on rhyolite and trachyte remain very low and present only a slight increase from the parent rock to the soils with values ranging from $0.45-1.15 \%$. The trend in $\mathrm{MnO}$ and $\mathrm{P}_{2} \mathrm{O}_{5}$ are similar and remain very low in all the profiles. Their concentrations are slightly higher in soils on basalt profile relative to the others. The highest concentration of $\mathrm{P}_{2} \mathrm{O}_{5}(0.97 \%)$ is registered in the $\mathrm{BC} 1$ phase while that of $\mathrm{MnO}(0.68 \%)$ in the $\mathrm{TC} 1$ phase.

\subsubsection{Levels and distribution of trace elements}

The concentrations of the analyzed trace elements are presented in table 3 . The concentration of trace elements vary from one profile to another, in soils developed on basalt, the concentrations of trace elements can be grouped into; (1) Elements whose concentration increases and reduces from the rock to the soils phases, they include; V, Zr, Cr, Nb, Rb, Ga and Hf. (2) Elements whose concentration remain fairly constant they include; Y, W, Cs Ta Sn and Th and (3) Element whose concentration reduces from the rock to the soil matrix, they include; $\mathrm{Ba}$ and $\mathrm{Sr}$. The most abundant trace elements in soil on basalt in order of decreasing abundance are; Zr: 773, V: 654, Cr: 470, Ba: 265, Nb: 146.

Table 3: Trace and REE Content of Soils from the Bamenda Mountain

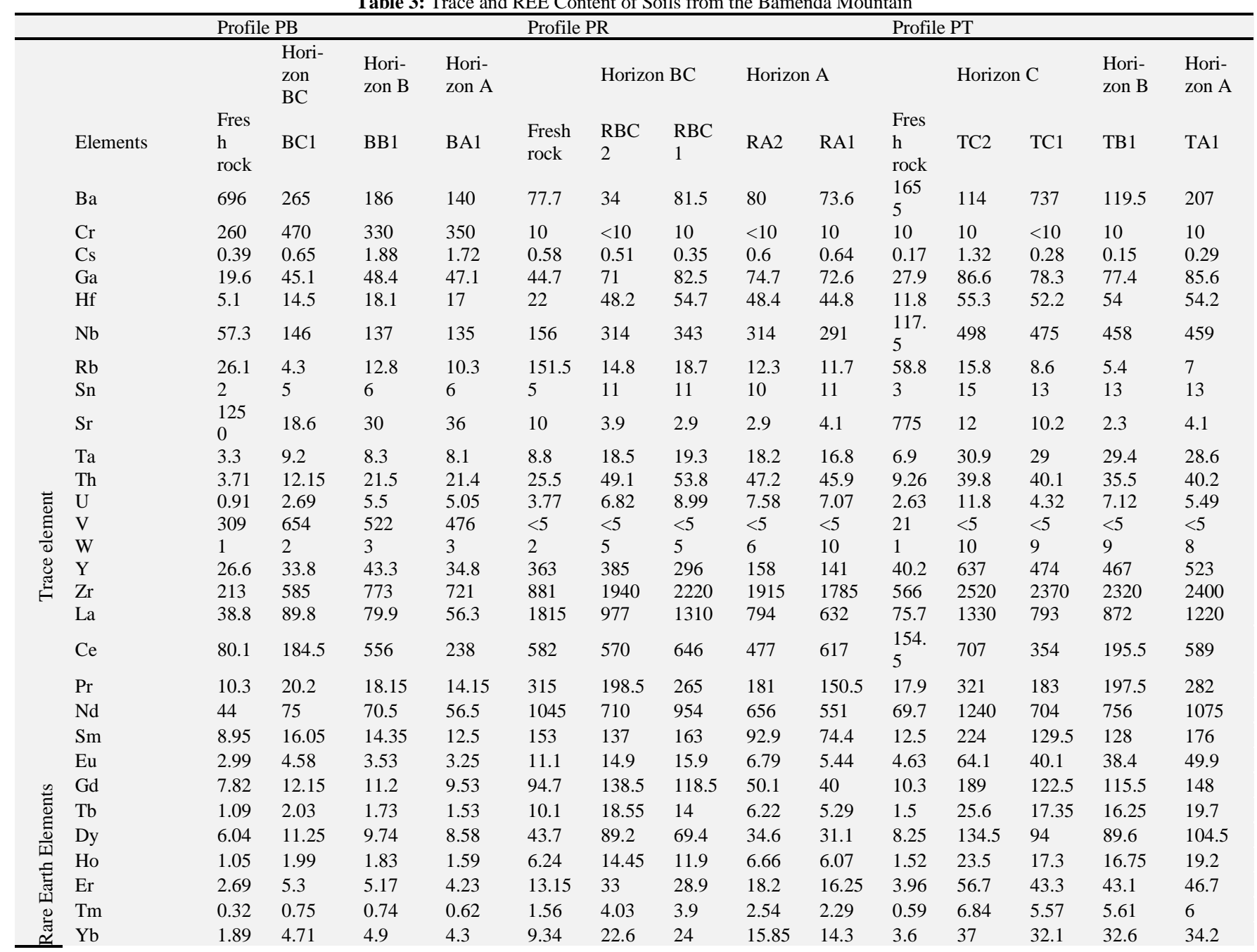




\begin{tabular}{|c|c|c|c|c|c|c|c|c|c|c|c|c|c|c|}
\hline $\mathrm{Lu}$ & 0.28 & 0.64 & 0.69 & 0.61 & 1.37 & 3.48 & 3.63 & 2.45 & 2.15 & 0.52 & 5.17 & 4.59 & 4.72 & 4.93 \\
\hline$\sum \mathrm{REE}$ & $\begin{array}{l}206 . \\
3\end{array}$ & 429.0 & 778.4 & 411.7 & $\begin{array}{l}4101 . \\
3\end{array}$ & $\begin{array}{l}2931 . \\
2\end{array}$ & $\begin{array}{l}3628 . \\
1\end{array}$ & $\begin{array}{l}2344 . \\
3\end{array}$ & $\begin{array}{l}2147 . \\
8\end{array}$ & $\begin{array}{l}365 . \\
2\end{array}$ & $\begin{array}{l}4364 . \\
4\end{array}$ & $\begin{array}{l}2540 . \\
3\end{array}$ & 2511.5 & 3775.1 \\
\hline$\sum$ LREE & $\begin{array}{l}185 . \\
1\end{array}$ & 390.1 & 742.4 & 380.7 & $\begin{array}{l}3921 . \\
1\end{array}$ & $\begin{array}{l}2607 . \\
4\end{array}$ & $\begin{array}{l}3353 . \\
9\end{array}$ & $\begin{array}{l}2207 . \\
7\end{array}$ & $\begin{array}{l}2030 . \\
3\end{array}$ & $\begin{array}{l}334 . \\
9\end{array}$ & $\begin{array}{l}3886 . \\
1\end{array}$ & $\begin{array}{l}2203 . \\
6\end{array}$ & 2187.4 & 3391.9 \\
\hline$\sum$ HREE & 21.2 & 38.8 & 36.0 & 31.0 & 180.2 & 323.8 & 274.2 & 136.6 & 117.5 & 30.2 & 478.3 & 336.7 & 324.1 & 383.2 \\
\hline $\begin{array}{l}\sum_{\mathrm{EE}} \mathrm{LREE} / \sum \mathrm{HR} \\
\end{array}$ & 8.7 & 10.0 & 20.6 & 12.3 & 21.8 & 8.1 & 12.2 & 16.2 & 17.3 & 11.1 & 8.1 & 6.5 & 6.7 & 8.9 \\
\hline $\mathrm{Eu} / \mathrm{Eu}^{*}$ & 1.1 & 1.0 & 0.9 & 0.9 & 0.3 & 0.3 & 0.4 & 0.3 & 0.3 & 1.3 & 1.0 & 1.0 & 1.0 & 1.0 \\
\hline $\mathrm{LaN} / \mathrm{YbN}$ & 14.0 & 13.0 & 11.1 & 8.9 & 132.3 & 29.4 & 37.2 & 34.1 & 30.1 & 14.3 & 24.5 & 16.8 & 18.2 & 24.3 \\
\hline
\end{tabular}

In soil developed on rhyolite, the behaviour and concentration of the elements are groups into; (1) Elements whose concentration increases and reduces from the rock to the soil phases, they include: Ga, Hf, Nb, Ta, Sn, Th, U, Zr. (2) Elements whose concentration reduce and increase from the rock to the soil, they include; $\mathrm{Ba}, \mathrm{Rb}, \mathrm{Sr}$ and $\mathrm{Y}$. (3) Elements whose concentration remain fairly constant from the rock to the soils, they include; $\mathrm{Cr}$, Cs and V. The most abundant trace elements in this profile in decreasing abundance are; Zr: 2220, Y: 385, Rb: 343, Ga: 82.5, Ba: 81.5, Hf: 54.7, Th: 53.8 .

In soils developed on trachyte, elements are also grouped as follows: (1) Elements whose concentration increases and decreases from the rock to the soils they include: $\mathrm{Ta}, \mathrm{Ga}, \mathrm{Nb}, \mathrm{Zr}, \mathrm{Hf}, \mathrm{Sn}, \mathrm{Th}$, $\mathrm{U}$, and Y; (2) Elements whose concentration reduces and increases from the rock to the soil; they include; $\mathrm{Ba}, \mathrm{Rb}, \mathrm{Sr}$ and $\mathrm{Va}$; (3) Elements whose concentration remain fairly constant from rock to soil, they include; $\mathrm{Cr}$, Cs and $\mathrm{W}$. The most abundant trace elements in this profile in order of decreasing abundance are: $\mathrm{Zr}$ : 2520, Ba: 737, Y; 637, Nb: 498, Ga: 86.5, Th: 40.1, Ta: 30.9.

\subsubsection{Behaviour of REE}

The concentrations of the analysed REEs are presented in table 3, the spider diagram of the analysed trace elements are presented in Fig.2. The behaviour of REE in the soils also varies from one profile to another. In soils developed on basalt, the concentration of $\sum \mathrm{REE}$ is the lowest relative to the others. In this soil profile, the soil phases are more enriched in REE from the parent rock to the BB1 phase (778.4) before decreasing at BA1 phase (411.7) at the surface. $\sum$ HREE remain very low in the soil phases with highest values of 38.8. The most abundant LREE in this profile is $\mathrm{Ce}$ (556) in the BB1 phase, followed by $\mathrm{La}(89.8 \mathrm{ppm})$ in the $\mathrm{BC} 1$ phase and $\mathrm{Nd}$ (75) in the $\mathrm{BC} 1$ phase. In soils developed on rhyolite, the concentration of $\sum \mathrm{REE}$ and $\sum \mathrm{LREE}$ alternately decrease and increase from the parent rock to the surface. The LREE vary from 3,353.9 in the RBC2 phase to 2,030.3 in the RA1 phase. $\sum$ HREE remain very low in this profile and slightly increase from the soil up to RBC1 phase before reducing to the surface. The most abundant LREE is La (1310), Nd (954) and Ce (646) all in the $\mathrm{BC} 1$ phase. In soils developed on trachyte, the concentration of REE and $\sum$ LREE have a similar trend and all increase in the soil TC2 before decreasing to TB1 phase and finally increase again in the TA1 phase. LREE here vary from 3,886 to 2,187 . HREE are also low in this profile and has a similar trend as the LREE. The most abundant LREE here are La $(1,330), \mathrm{Nd}(1,240)$ and $\mathrm{Ce}$ (707) all in the TC2 phase. The REE fractionation index ranges from 6.1 in soils on trachyte to 20.6 in soils on basalt. The $\mathrm{Eu} / \mathrm{Eu}^{*}$ values also range from 0.9 to $1.0 .(\mathrm{La} / \mathrm{Yb}) \mathrm{N}$ values range from 11.1 in $\mathrm{BB} 1$ phase to 37.2 in the $\mathrm{RBC} 1$ phase in soils on rhyolite. The normalized pattern for the REE normalized on $\mathrm{CI}$ chondrite indicates a decrease in concentration from LREE to HREE. The patterns of samples developed on basalt are collinear but, BB1 and BA1 phases show a positive Ce anomaly. PR and PT soils also present a collinear pattern, both present a negative anomaly in $\mathrm{Ce}$ in all the soil phases, but only soils developed on rhyolite show a negative Eu anomaly.

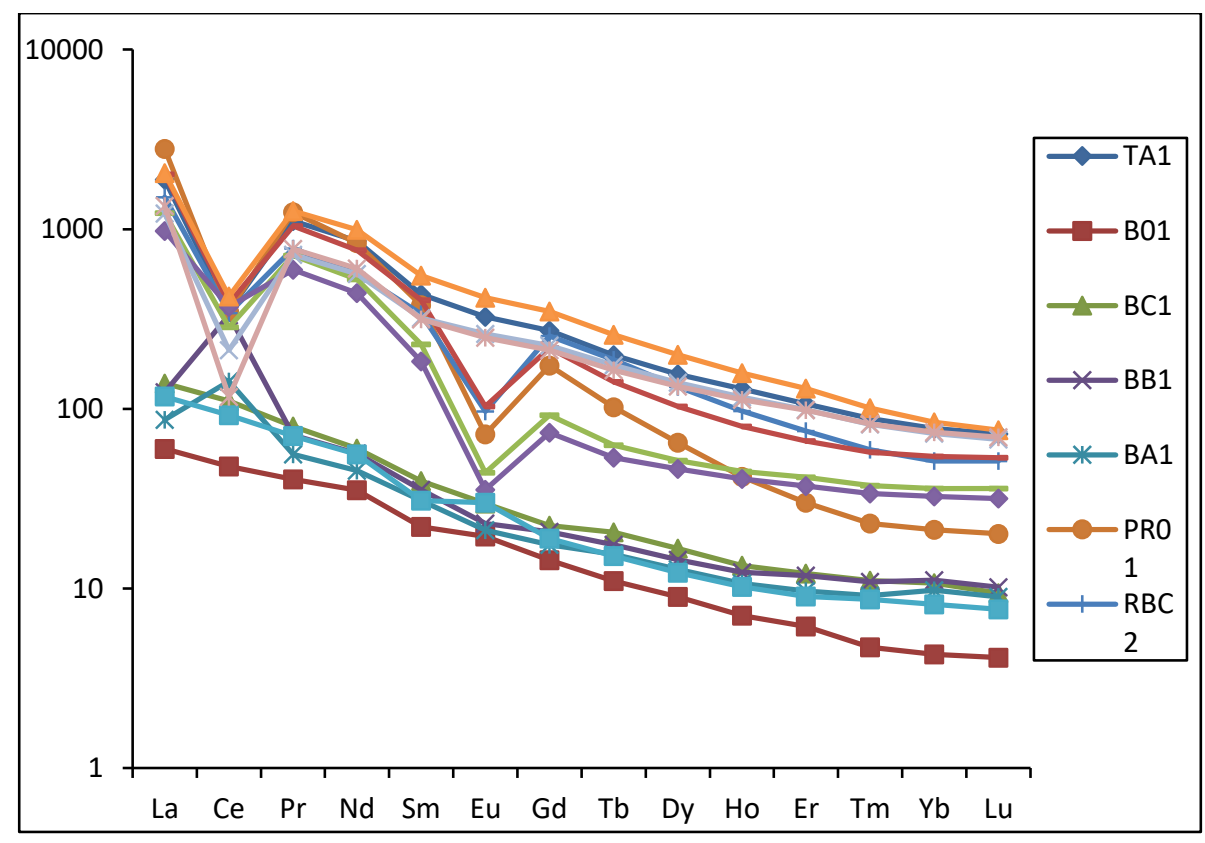

Fig. 2: Spider Diagram Diagram for REE Element Composition of Soils Samples (Boynton 1984).

\subsubsection{Weathering indices}

The molar ratio $\mathrm{Ki}=\mathrm{SiO}_{2} / \mathrm{Al}_{2} \mathrm{O}_{3}$ of the soils decrease abruptly from the fresh rock to the soil phases in all the 3 profiles. The lowest $\mathrm{Ki}$ values (0.34-0.57\%) are registered in soils developed on basalt. From the weathering indices of the soils, $\mathrm{Ki}=\mathrm{SiO}_{2} / \mathrm{Al}_{2} \mathrm{O}_{3}$ which indicates the silica leaching intensity indicates silica is highly leached in soils on basalt (0.34-3.57), while in soils on rhyolite and trachyte $\mathrm{Ki}=1.56-2.21$, this indicates low leaching of silica in this environment and thus reinforcement of the presence of 2:1 clays (Tematio et al. 2012). The molar ratio of $\mathrm{Fe}_{2} \mathrm{O}_{3} / \mathrm{K}_{2} \mathrm{O}$, 
presents a very clear contrast in soils on basalt with very high values, the highest (495) registered in the $\mathrm{BC} 1$ phase and this value decreases as we move towards the surface $139.41 \%$. Conversely this ratio remains very low in the soils on rhyolite and trachyte with values ranging from 11.9-38.5\%. These high values can be attributed to the presence of primary minerals such as olivine and pyroxenes in the basalt. Increase in $\mathrm{Fe}_{2} \mathrm{O}_{3}$ results from chemical weathering in an oxidizing environment (Birkeland 1984). The weathering indices increase in the soil, thus indicating intense chemical weathering in this environment.

The ratio of Bases $/ \mathrm{R}_{2} \mathrm{O}_{3}$ drops significantly from parent rocks to soils in all the soil profiles, with only soil samples on trachyte presenting values $>3$. The relatively low values of $\mathrm{Bases} / \mathrm{R}_{2} \mathrm{O}_{3}$ (0.71-6.09) in all the soil phases in the profiles highlights intense leaching of alkaline and alkali-earth elements in this environment (Schroeder et al. 2000). This value increases with depth due to the mobility of these elements. This can also be attributed to intense chemical weathering in tropical environments. CIA and CIW present similar trends in all the profiles, with CIA values higher than CIW. Their values increase from the parent rock to the soils and as one move towards the surface. Soils developed on basalt has the lowest CIW (72.73-74.11) and CIA (72.62-73.84) values. The highest values in CIW (98.61-98.8) and CIA (97.1-97.68) are registered in soils on rhyolite. The very high values in CIW and CIA indicates an advance to extreme chemical weathering in this environment, with soil on rhyolite being the most highly weathered followed by those on trachyte and finally those on basalts. TRB is significantly low in all the soil profiles pointing to the fact that the basic cation are easily dissolved and leached in this environment (Herbillon 1988), corroborating intense chemical weathering. The ICV in all the soil profiles is lower than that of the parent rock. The ICV in soils developed on basalts (1.0-1.4) is higher indicating these soils are young and immature than those produced on trachytes $(0.25-0.31)$ and rhyolites $(0.41-0.5)$ relating to greater chemical weathering and the presence of higher clay content in the soils (Cox et al. 1995). The Silica/sesquioxide ratio (S) is low in the soils developed on basalts thus indicating a leaching of $\mathrm{SiO}_{2}$ in soils developed on basalt, while soils developed on trachyte (PT) and on rhyolite (PR), have higher values thus indicating lesser leaching of $\mathrm{SiO}_{2}$. This is evidence of warm and wet soil-forming processes of ferrallitization at moderate $\mathrm{pH}$, in tropical environments (Retallack 2001).

\subsubsection{Chemical mass balance}

Enrichment-depletion of the elements in the soil profile was done using the enrichment factors (EF) (table 4). Elements with $\mathrm{EF}>1.0$ are referred to as enriched while $\mathrm{EF}<1.0$ are referred to as depleted. Major and trace elements in various soil phases are grouped into enriched $(\mathrm{EF}=1.0)$, depleted $(\mathrm{EF}<1.0)$ or alternately enriched-depleted $(\mathrm{EF} \pm 1.0)$ elements (Table 4). In the PB profile, $\mathrm{SiO}_{2}$ is highly depleted in the soil phases with maximum $\mathrm{EF}_{\mathrm{Si}}=$ 0.3 . $\mathrm{Al}$ and $\mathrm{Fe}$ are slightly depleted before being enriched upward the profile, with $\mathrm{EF}_{\mathrm{Al}}=1.5$ and $\mathrm{EF}_{\mathrm{Fe}}=1.3$. In the PR and PT profiles, $\mathrm{Al}$ and $\mathrm{Fe}$ are depleted in all the soil phases except for TB1 phase with $\mathrm{EF}_{\mathrm{Al}}=1.5$. $\mathrm{Ca}, \mathrm{Mg}, \mathrm{Na}$ and $\mathrm{K}$ are almost completely depleted as weathering takes place, with $\mathrm{EF}$ values ranging from $0-0.1$. $\mathrm{Mn}, \mathrm{Cr}$ and $\mathrm{P}$ are also depleted in the soil phases from the rock to the soil phases for all the soils profiles. In soil on basalt, trace elements are highly depleted in all the soil phases, with $\mathrm{EF}=<0.5$. $\mathrm{Ba}, \mathrm{Rb}, \mathrm{Sr}$ and $\mathrm{Cr}$ are slightly depleted, while elements like $\mathrm{Cs}, \mathrm{Ga}, \mathrm{Nd}$ and $\mathrm{V}$ are slightly depleted in the $\mathrm{BC} 1$ soil phase before being enriched in the other phases. Nd is alternatively depleted and enriched in the soil. The most enriched elements are in the $\mathrm{BB} 1$ soil phases which are: $\mathrm{EF}_{\mathrm{U}}=4.2, \mathrm{EF}_{\mathrm{Th}}=4, \mathrm{EF}_{\mathrm{Cs}}=3.3$ and $\mathrm{EF}_{\mathrm{Hf}}=2.5, \quad \mathrm{EF}_{\mathrm{Sn}}=2.01, \quad \mathrm{EF}_{\mathrm{Ta}}=1.74, \quad \mathrm{EF}_{\mathrm{W}}=2.07, \quad \mathrm{EF}_{\mathrm{Y}}=1.13$, $\mathrm{EF}_{\mathrm{Zr}}=2.52$. Depleted elements are: $\mathrm{Ba}=0.2, \mathrm{Cr} 0.7$, and $\mathrm{Rb}=0.4$.

In soil on rhyolite, $\mathrm{Si}$ is depleted in the various soils phases from the rock to the soil phases, with maximum values of $\mathrm{EF}_{\mathrm{Si}}=0.4 \mathrm{Al}$ and $\mathrm{Fe}$ are slightly depleted in this profile, however, they remain the most abundant, with values $\mathrm{EF}_{\mathrm{Al}}=0.9$ and $\mathrm{EF}_{\mathrm{Fe}}=0.8$. These elements are enriched up the profile. $\mathrm{Ca}, \mathrm{Mg}, \mathrm{Na}$ and $\mathrm{K}$ are highly depleted in this profile; however, the rate of depletion in $\mathrm{Mg}$ is less than that of the other elements. $\mathrm{Cr}$ and $\mathrm{P}$ are depleted in this profile and $\mathrm{Mn}$ is enriched with $\mathrm{EF}_{\mathrm{Mn}}=5.7$ registered in the $\mathrm{RBC} 1$ phase.

Regarding trace elements, Enriched elements are $\mathrm{EF}_{\mathrm{Hf}}=2.1$, EF$\mathrm{Ba}=1, \mathrm{EF}_{\mathrm{Cr}}=1.05, \mathrm{EF}_{\mathrm{Ga}}=1.7, \mathrm{EF}_{\mathrm{Nb}}=2.0, \mathrm{EF}_{\mathrm{W}}=1.4, \mathrm{EF}_{\mathrm{Z}}=1, \mathrm{EF}_{\mathrm{Sn}}=2.4$, $\mathrm{EF}_{\mathrm{Ta}}=1.9, \quad \mathrm{EF}_{\mathrm{Th}}=1.9, \quad \mathrm{EF}_{\mathrm{Cs}}=1.2, \quad \mathrm{EF}_{\mathrm{Nb}}=2.0, \quad \mathrm{EF}_{\mathrm{Sn}}=1, \quad \mathrm{EFY}=1.4$, $\mathrm{EF}_{\mathrm{Zr}}=1$. Depleted elements are $\mathrm{EF}_{\mathrm{Cr}}=0.4, \mathrm{EF}_{\mathrm{Ba}}=0.2, \mathrm{EF}_{\mathrm{Cs}}=0.7$ and $\mathrm{EF}_{\mathrm{Rb}}=0.04, \mathrm{EF}_{\mathrm{Sr}}=0.2, \mathrm{EF}_{\mathrm{U}}=0.8, \mathrm{EF}_{\mathrm{V}}=0.5$.

In soil on trachyte, $\mathrm{Si}$ is highly depleted from the rock to the soil with $\mathrm{EF}_{\mathrm{Si}}=0.3$. $\mathrm{Al}$ are also depleted in these soils from the rock to the soil phases $\mathrm{EF}_{\mathrm{Al}}=0.6$, though $\mathrm{Fe}$ is depleted in this profile, it is enriched in the TB1 phase $\mathrm{EF}_{\mathrm{Fe}}=1.5$. $\mathrm{Ca}, \mathrm{Mg}, \mathrm{Na}$ and $\mathrm{K}$ are highly depleted with maximum values of $\mathrm{EF}_{\mathrm{Mg}}=0.3 . \mathrm{Cr}$ and $\mathrm{P}$ are also depleted in all the soil phases. Mn is also enriched in the TC1 phase $\mathrm{EF}_{\mathrm{Mn}}=1.4$.

Enriched trace elements are: $\mathrm{EF}_{\mathrm{Cs}}=2.8, \quad \mathrm{EF}_{\mathrm{Ga}}=1.1, \quad \mathrm{EF}_{\mathrm{Hf}}=1.7$, $\mathrm{EF}_{\mathrm{Nb}}=1.7, \mathrm{EF}_{\mathrm{Sn}}=1.8, \mathrm{EF}_{\mathrm{Ta}}=1.6, \mathrm{EF}_{\mathrm{U}}=1.6, \mathrm{EF}_{\mathrm{Y}}=5.6, \mathrm{EF}_{\mathrm{W}}=3.5$, $\mathrm{EF}_{\mathrm{Zr}}=1.6, \mathrm{EF}_{\mathrm{Th}}=1.7$. Depleted elements are; $\mathrm{EF}_{\mathrm{Ba}}=0.02, \mathrm{EF}_{\mathrm{Cr}}=0.4$, $\mathrm{EF}_{\mathrm{Rb}}=0.1$ and $\mathrm{EF}=0.01$.

Generally, incompatible trace elements are more enriched in the soil phases than compatible and major elements, with Mn (5.7) being the most enriched element in the soil.

Table 4: Major and Trace Element Balance

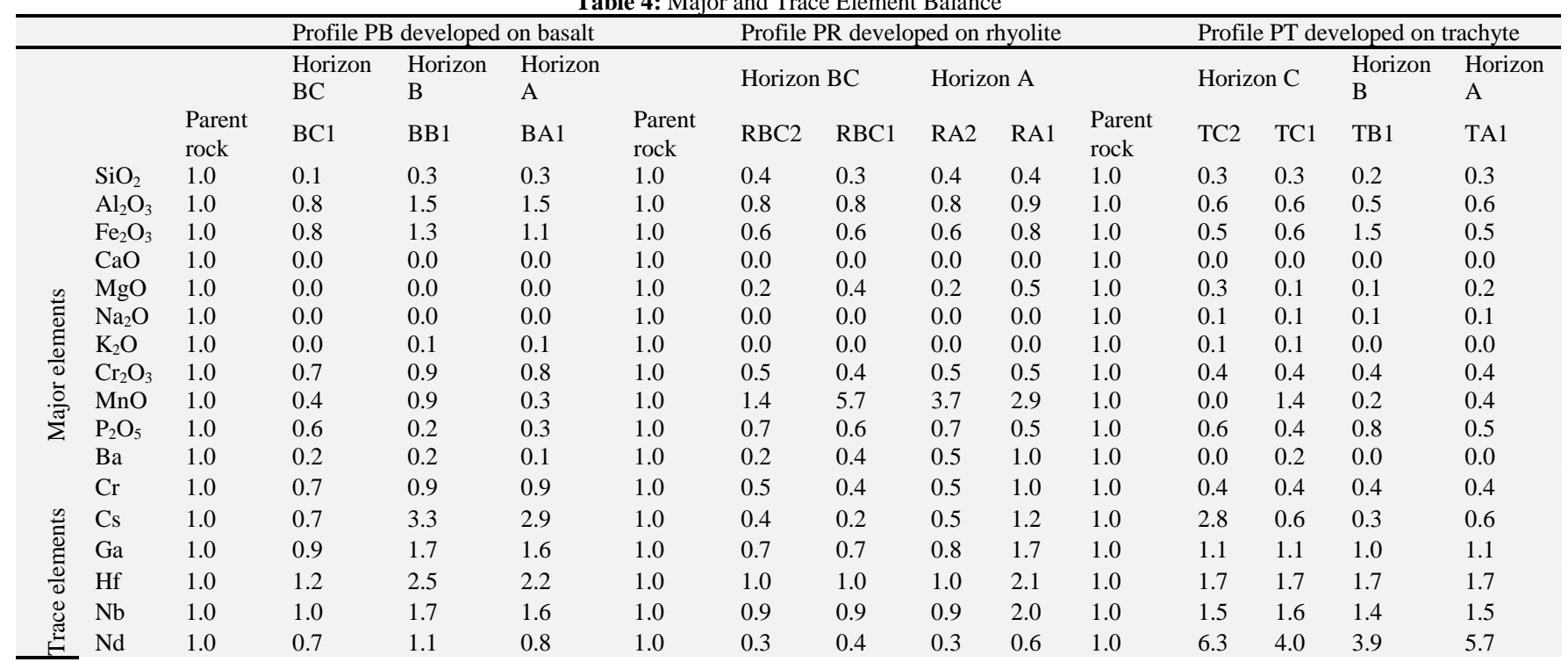




\begin{tabular}{|c|c|c|c|c|c|c|c|c|c|c|c|c|c|c|}
\hline $\mathrm{Rb}$ & 1.0 & 0.1 & 0.3 & 0.3 & 1.0 & 0.0 & 0.0 & 0.0 & 0.1 & 1.0 & 0.1 & 0.1 & 0.0 & 0.0 \\
\hline $\mathrm{Sn}$ & 1.0 & 1.0 & 2.1 & 2.0 & 1.0 & 1.0 & 0.9 & 0.9 & 2.3 & 1.0 & 1.8 & 1.7 & 1.6 & 1.6 \\
\hline $\mathrm{Sr}$ & 1.0 & 0.0 & 0.0 & 0.0 & 1.0 & 0.2 & 0.1 & 0.1 & 0.4 & 1.0 & 0.0 & 0.0 & 0.0 & 0.0 \\
\hline $\mathrm{Ta}$ & 1.0 & 1.1 & 1.7 & 1.6 & 1.0 & 1.0 & 0.9 & 0.9 & 2.0 & 1.0 & 1.6 & 1.6 & 1.5 & 1.5 \\
\hline $\mathrm{U}$ & 1.0 & 1.2 & 4.2 & 3.7 & 1.0 & 0.8 & 1.0 & 0.9 & 2.0 & 1.0 & 1.6 & 0.6 & 1.0 & 0.8 \\
\hline V & 1.0 & 0.9 & 1.2 & 1.0 & 1.0 & 0.5 & 0.4 & 0.5 & 1.0 & 1.0 & 0.1 & 0.1 & 0.1 & 0.1 \\
\hline W & 1.0 & 0.8 & 2.1 & 2.0 & 1.0 & 1.1 & 1.0 & 1.4 & 5.2 & 1.0 & 3.5 & 3.5 & 3.3 & 3.0 \\
\hline
\end{tabular}

\subsection{Geotechnical characterization of soils}

Within each well, disturbed and undisturbed soil samples were collected at $1 \mathrm{~m}$ interval. Within soils developed on basalt, samples collected were denoted: (PB01, PB02, PB03 and PB04); for soils on trachyte: (PT01, PT02, PT03 and PT04) and those on rhyolite: (PR01, PR02, PR03 and PR04). The results of particle size analysis obtained from wet/dry sieving and sedimentation tests are summarized in Table 5. Globally the percentage of gravel is very low for all the samples averaging $0.6 \%$, followed by clays with approximately $16 \%$. Most of the soil particles fall within the sand and silt domain, accounting for 39 and $43 \%$ percent of the particle sizes respectively. Relatively, silts are most abundant in samples on basalt and rhyolite, while sand is most abundant in soil developed on trachyte.

Table 5: Percentage Distribution of Grain Sizes in the Three Profiles

\begin{tabular}{|c|c|c|c|c|c|}
\hline Sample & $\begin{array}{l}\text { Depth } \\
\text { (m) }\end{array}$ & $\begin{array}{l}\text { Gravel } \\
\Phi \\
>2 \mathrm{~mm}\end{array}$ & $\begin{array}{l}\text { Sand } 2>\Phi \\
>0.02 \mathrm{~mm}\end{array}$ & $\begin{array}{l}\text { Silt } 0.02>\Phi \\
>0.002 \mathrm{~mm}\end{array}$ & $\begin{array}{l}\text { Clay } \Phi \\
<0.002 \mathrm{~mm}\end{array}$ \\
\hline PR01 & 1 & 0.3 & 20.6 & 58.6 & 20.5 \\
\hline PR02 & 2 & 0.2 & 17.7 & 60.4 & 21.7 \\
\hline PR03 & 3 & 0.2 & 19.7 & 59.9 & 20.2 \\
\hline PR04 & 4 & 0.3 & 21 & 59.2 & 19.5 \\
\hline РT01 & 1 & 2.4 & 53.1 & 31.6 & 12.9 \\
\hline РT02 & 2 & 0.7 & 55.8 & 32.1 & 11.4 \\
\hline РT03 & 3 & 0.3 & 48.3 & 37.7 & 13.7 \\
\hline PT04 & 4 & 0.9 & 73 & 18.6 & 7.5 \\
\hline PB01 & 1 & 0.9 & 43.2 & 35.7 & 20.2 \\
\hline PB02 & 2 & 0.4 & 33.9 & 46.2 & 19.5 \\
\hline PB03 & 3 & 0.4 & 32.1 & 51.6 & 15.9 \\
\hline PB04 & 4 & 0.7 & 35.4 & 40.5 & 23.4 \\
\hline
\end{tabular}

The particle size distribution curve does not show any significant difference in grading with increasing depth from 1 to $4 \mathrm{~m}$ in all the profiles. These soil samples present a wide range of particle sizes and are thus well graded. Samples PT01 to PT03 show a similar pattern and are well graded, while sample PT04 presents a gap grading.

The methylene absorption test values for soils developed on rhyolite indicates clay content increases with increasing depth from 1 to $4 \mathrm{~m}$, ranging from silty - clayey - very clayey soils (Table 6). Soils on trachyte have MBV values between 2 and 3.87 and fall within the silty - silty clay soils domain. The clay content also increases with depth. For soil on basalt, clay content does not increase with depth but remain fairly constant and fall within the very clayey soil domain. The amount of clay is lowest for soils on trachyte, its amount increases with depth. This is followed by soil on basalt whose value remains fairly constant with increasing depth from at 1 to $4 \mathrm{~m}$. Soil on rhyolite, has the highest amount of clay and it increases with increasing depth from at 1 to $4 \mathrm{~m}$.

The physical parameters of the studied samples are presented in table 7. Liquid limit (LL) shows a progressive increase in soil samples from PR01 to PR03 with increasing depth from 1 to 3 meters, however, at $4 \mathrm{~m}$ the water content drops. The LL for soil on trachyte shows a slight increase with depth and reduces slightly from 3 to $4 \mathrm{~m}$. Soil on basalt increases from 1 to $2 \mathrm{~m}$ and remains fairly constant with increasing depth. The plastic limit (PL) for all the soil samples shows a similar trend with increasing depth. The PL increases with increasing depth up to $3 \mathrm{~m}$ and then at $4 \mathrm{~m}$ depth. Soil on trachyte presents the highest PL relative to the others.

Plastic limit is highest for soil on trachyte and does not show any significant difference in values with increasing depth. This is fol- lowed by soils on rhyolite, with no significant difference with increasing depth. Soil on basalt has an irregular trend but lower than the other soil samples. Its values increases at depth of 1-2m, then reduces at $3 \mathrm{~m}$ and significantly increase $4 \mathrm{~m}$.

Plasticity index (PI) it is an indicator of how much water the soil particles in the specimen can absorb. In soil samples PR increases slightly at $1 \mathrm{~m}$ up to $3 \mathrm{~m}$ and drops slightly at $4 \mathrm{~m}$. Soils on trachyte, PI decrease at 1 to $3 \mathrm{~m}$ and increase slightly at $4 \mathrm{~m}$. A soil on basalt present the lowest PI values and increases slightly at 1 to $2 \mathrm{~m}$ and drops at $3 \mathrm{~m}$ and finally increase at $4 \mathrm{~m}$. All the soil samples fall within the less plastic domain, and moderately plastic following the degree of plasticity.

The consistency index values is highest at $1 \mathrm{~m}$ for soil on basalt, and reduces at $2 \mathrm{~m}$, then increase and finally at $4 \mathrm{~m}$ Ic is at its lowest. Soil on rhyolite has the highest values relative to all the other soils samples and decreases from 1 to $2 \mathrm{~m}$ and increases at $3 \mathrm{~m}$ before slightly dropping at $4 \mathrm{~m}$. The Ic is lowest for soil on trachyte and decreases with increasing depth from 1 to $4 \mathrm{~m}$.

The water content is highest for soil on trachyte followed by those on basalt and rhyolite. The water content in soil on trachyte increases with increasing depth up to $3 \mathrm{~m}$ and then slightly reduces at $4 \mathrm{~m}$. For soil on basalt, the water content at $1 \mathrm{~m}$ is lowest and alternately increases and reduces at $2 \mathrm{~m}, 3 \mathrm{~m}$ and $4 \mathrm{~m}$ respectively. In soil on rhyolite, water content is fairly constant doesn't change much with variation in depth.

The bulk and dry density shows a similar trend for all the soil samples with increasing depth. The density of the soils is highest for soils on basalt, followed by those on trachyte and rhyolite. For soils on basalt, the density decreases with increasing depth up to $3 \mathrm{~m}$ and increases at $4 \mathrm{~m}$. Soil on trachyte also follows the same trend as those on basalt. Soil on rhyolite reduces at $1 \mathrm{~m}$ to $2 \mathrm{~m}$ and then steadily increases with increasing depth.

The specific gravity is highest for soil on basalt and lowest for soils on rhyolite. For soils on basalt, the sg is fairly constant from 1 to $3 \mathrm{~m}$ and increases at $4 \mathrm{~m}$. In soil developed on trachyte, the sg decreases from 1 to $2 \mathrm{~m}$ and then remains fairly constant up to $4 \mathrm{~m}$. Soils on rhyolite have fairly constant sg with increasing depth.

The porosity and void index shows a similar evolution for the soil samples. For soil on rhyolite, both parameters increase from 1 to $2 \mathrm{~m}$ and then decreases with increasing depth. For soils developed on trachyte, these parameters decreases progressively with increasing depth from 1 to $4 \mathrm{~m}$. While soil on basalt has the lowest and highest values increasing with increasing depth.

Compacity is highest for soil on basalt at $1 \mathrm{~m}$ and decreasing with increasing depth at $4 \mathrm{~m}$ where it is lowest. Soils on trachyte and rhyolite show a gradual increase in compacity with increasing depth from 1 to $4 \mathrm{~m}$. Soil on rhyolite show a fairly constant saturation with increasing depth, while those on trachyte increases with depth up to $3 \mathrm{~m}$ and reduces at $4 \mathrm{~m}$. Soil on basalt increases from 1 to $2 \mathrm{~m}$ and alternately reduces and increases at $3 \mathrm{~m} 4 \mathrm{~m}$ depth

\subsubsection{Cohesion and internal friction angle}

The mechanical parameters determined for the soil on various rock types are presented in table 8 . These values indicate the soil strength is low and can easily slide when subjected to shear stress. Shear strength which is the maximum stress a material can withstand before it ruptures and deforms is determined by cohesion of grains and friction between grains. The higher these values the higher the shear strength of the soil. If slope angle is less than friction angle, slope is stable and vice versa. The lower the value of $\mathrm{c}$ the higher the $\Phi^{\prime}$ value and the more unstable a slope is. 


\section{Discussions}

\subsection{Weathering trends}

From the weathering indices of the soils, $\left(\mathrm{Ki}=\mathrm{SiO}_{2} / \mathrm{Al}_{2} \mathrm{O}_{3}\right)$ silica is highly leached in soils on basalt (0.34-3.57), while in soils on rhyolite and trachyte $(\mathrm{Ki}=1.56-2.21)$. This indicates low leaching of silica in this environment and thus reinforcement of the presence of 2:1 clays (Tematio et al. 2012). The relatively low value of Bases $/ \mathrm{R}_{2} \mathrm{O}_{3}$ (0.71-6.09) in all the phases in the profiles highlights intense leaching of alkaline and alkali- earth elements in this environment (Schroeder et al. 2000; Nesbitt et al. 1980). This value increases with depth due to the mobility of these elements. The low TRB in the soils point to the fact that the basic cation are easily dissolved and leached in this environment (Herbillon 1988), corroborating intense chemical weathering.

The CIA (72.62- 97.8) and CIW (72.76-98.8) which are related to the degree of weathering and is very high indicates advance to extreme chemical weathering in this environment (Nesbitt and Wilson 1992), with soils on rhyolite being the most highly weathered followed by those on trachyte and finally those on basalts. This lower CIA and CIW values indicates soils formed on basalt have the predominance of primary minerals with ICV values $>1$ indicating these soils are young and immature (Di Figlia et al. 2007; Tijani et al. 2006; Caspari et al. 2006; Price and Velbel 2003). Soil formed on rhyolites have ICV values of 0.3 and those on trachytes have ICV values of 0.4-0.5 thus indicating greater chemical weathering and the presence of higher clay content in the soils (Cox et al. 1995). From the ICV values, soils on basalt have high clay content; while soils on rhyolite are predominantly made up to kaolinite clays and soils on trachyte are made up of illites (Nesbitt and Young 1982). The Silica/sesquioxide ratio (S) is low in the soils developed on basalts thus indicating a leaching of $\mathrm{SiO}_{2}$ in these basic soils, while soils developed on trachyte and on rhyolite, have higher values thus synonymous to lesser leaching of $\mathrm{SiO}_{2}$. This is evidence of warm and wet soil-forming processes of ferrallitization at moderate $\mathrm{pH}$, in tropical environments (Retallack 2001). The $\mathrm{SiO}_{2} / \mathrm{Al}_{2} \mathrm{O}_{3}$ ratio has a value of 1-3 for soils developed on trachyte and rhyolite which points to the predominance of $1: 1$ clays minerals in all the soil, thus suggesting bisiallitisation took place in this environment (Wouatong et al. 2013; Birkeland 1999). The lowest values of the TRB in the soils may be indicative of this approximately complete weathering of primary minerals (Herbillon 1989).

The $\mathrm{Fe}_{2} \mathrm{O}_{3} / \mathrm{K}_{2} \mathrm{O}$ is high in the soil relative to the rocks. This can be attributed to the presence of primary minerals such as olivine and pyroxenes in the basalt. Increase in $\mathrm{Fe}_{2} \mathrm{O}_{3}$ results from chemical weathering in an oxidizing environment (Birkeland 1984). The weathering indices increase in the soil, thus indicating intense chemical weathering in this environment. $\mathrm{SiO}_{2}$ is depleted in the soils, this is due to the fact that it is normally present in excess in the parent rock more than it is necessary to form the clay mineral and therefore it always decrease with progressive weathering (Birkeland 1984).

The increase in the $\mathrm{Fe}$ and $\mathrm{Al}$ content in the soils can be attributed to the weathering of kaolinite and from primary minerals from the rock (Lambiv Dzemua et al. 2011; Ndjigui et al. 2008; Dequencey et al. 2002). The high concentration of REE in the soils can be attributed to the influence of secondary mineral development on the REE distribution during the weathering process. Strong positive $\mathrm{Ce}$ anomaly may be linked to oxidation of $\mathrm{Ce}^{3+}$ to $\mathrm{Ce}^{4+}$ or primary $\mathrm{Ce}^{4+}$ in residual zircon minerals because of its oxidation ability, insolubility and stability in lateritic environments (Ndjigui et al. 2008). The positive anomaly in Ce could be from the oxidation of $\mathrm{Ce}^{3+}$ into $\mathrm{Ce}$ in the soil solution, which would be further co-precipitated with $\mathrm{Fe} / \mathrm{Mn}$ (hydroxides) and form $\mathrm{CeO}_{2}$ or $\mathrm{Ce}$ (OH) (Marker and De Oliveira 1990). These Ce species were insoluble and would be enriched in the soils' secondary minerals, which consequently resulted in a positive Ce anomaly (Feng 2010; Ohnuki et al. 2008). The negative Ce anomalies in soils on tra- chyte and rhyolite show that $\mathrm{Ce}$ exists in trivalent form as other REE $^{3+}$ (Kamgang et al. 2009; Ndjigui et al. 2009; Leybourne et al. 2000; Marsh 1991).

The enrichment of some elements in the soil phases could originate from the alteration of the basic, intermediary and acidic rocks in the area. It may also be from relative enrichment during hydrolysis in association with Fe-oxides (Singh et al. 2002) during which poor rare metals accumulate due to poor leaching (Fouateu et al. 2006). It may also result from the slow and partial distribution of the neosynthesis of secondary minerals through weathering (Singh et al. 2002). It could also result from the intense biological activity due to recycling process of metals by plants at the surface (Kabata-Pendias 2001).

The strong Eu anomaly in the soils generated from trachyte and rhyolite could be as a result of high temperatures and rainfall in the environment which strengthened the mineral weathering and element leaching which resulted in the formation and fractionation of more active REEs (Chunying et al. 2016; Huang et al. 2008). Positive Eu anomalies may have resulted from the substitution of $\mathrm{Eu}$ with Sr. REE could have resulted from the accumulated of Fe-, $\mathrm{Al}-$ and Mn-oxides with the accumulation of secondary minerals of $\mathrm{Fe}-, \mathrm{Al}-$ and $\mathrm{Mn}$ - oxides. In contrast to $\mathrm{Eu}, \mathrm{Ce}$ shows a positive anomaly in soils on basalt and a negative anomaly in those on rhyolite and trachyte.

\subsection{Geochemical transformations}

The main process of soil formation on soils developed on basalt is ferralitisaton; it involves intense weathering of primary and secondary minerals, followed by the leaching of alkaline and alkaliearth elements and to a greater part of quartz with a mobilization rate of $(77 \%)$, with the accumulation of allumino-silicates like kaolinite, aluminium hydroxides and $\mathrm{Fe}$-oxides and hydroxides. This process is also corroborated by the high weathering indices in the soils and total leaching of alkaline and alkali-earth elements. The composition of soils is modified during bedrock chemical weathering (Di Figlia et al. 2007). It is usually characterized by the progressive loss of the bases $\left(\mathrm{CaO}, \mathrm{MgO}, \mathrm{Na}_{2} \mathrm{O}\right.$ and, $\left.\mathrm{K}_{2} \mathrm{O}\right)$, enrichment of sesquioxides $\left(\mathrm{Al}_{2} \mathrm{O}_{3}, \mathrm{Fe}_{2} \mathrm{O}_{3}\right.$ and $\left.\mathrm{TiO}\right)$, and an increase in water as indicated by the loss on ignition (LOI) (Tijani et al. 2006). Chemical index of alteration (CIA) has been proposed as a good indicator for the degree of weathering (Di Figlia et al. 2007; Caspari et al. 2006; Tijani et al. 2006; Price and Velbel 2003).

REE usually result from the parent rock and soil of which have high REE (Berger et al. 2014) minerals with a high REE content are more likely to control the REE signature of the parent rock as well as the subsequent secondary minerals (Laveuf and Cornu 2009) including $\mathrm{Fe}$ - and Mn-oxides, are recognized as important REE scavengers (Yusoff et al. 2013; Galan et al. 2007; Ohlander et al. 1996) and can fractionate REEs through a variety of geochemical processes, particularly surficial sorption (Sanematsu et al. 2013; Lopez et al. 2007). REE behavior in surface soils is closely related to interactions with secondary minerals, especially geochemically active secondary minerals such as $\mathrm{Fe}-$, $\mathrm{Al}-$, and Mn-oxides (Babechuk et al. 2014; Ndjigui et al. 2008). Furthermore, the distribution and fractionation of REEs are highly variable in different soils due to variations in secondary minerals (Yusoff et al. 2013; Galan et al. 2007).

Negative Ce values are uncommon in soils and are encountered in trachyte and rhyolites-here. This negative $\mathrm{Ce}$ anomaly has also been recorded in weathered amphibolite products in the SW of Eseka, with high Ce values (Bayiga et al. 2011). Leaching of alkalis elements is common in tropical humid environments with the accumulation of $\mathrm{Fe}$, and $\mathrm{Al}$ oxides. This tendency has also been reported in other areas along the CVL (Tematio et al. 2012; 2009). LREE are enriched in the soil phase here and is probably due to enrichment from the parent rock (Braun et al. 1993).

\subsection{Geotechnics}


Grain size distribution classes the grains into sand, silt and clays, with most of the particle sizes predominantly silts. The nature of the curve for all the samples covers a wide range of particle sizes, indicating the soil is well graded (Terence 2011). However sample PT04 has a gap grading. The high amount of coarse particles in the soil developed on trachyte can be as a result of the presence of primary minerals in the rock such as; high silica content $(63.4 \%)$ in the weathered saprolite and unweathered particles of alkaline feldspar. Conversely to Wouatong et al (2014) who suggest the predominance of coarse particles in soils developed on trachyte studied in Fongo-Tongo is due to a pronounced induration at this profile level. The high clay content in rhyolite is as a result of accumulation of clays minerals following high degree of weathering in these rocks, with the presence of kaolinite due to their ICV values of 0.3 . Soil mineralogy influences the behaviour of soils as it affects ion exchange, hydration and swelling, flocculation and dispersion, preferential flow, barrier flows and chemical adsorption of contaminants and nutrients (Fell 2000). Most weathering indices are indicative of high leaching intensity in the rocks. The well graded nature of the samples in indicative of the fact that weathering in the area in high and the profiles are shallow.

Soil samples developed on rhyolite has the highest clay content which increases with depth. This indicates the nature of the soil changes from silty clay soils to clayey soils according to the methylene blue values chart. Soil samples developed on trachyte have lower clay content and fall within the silty soil to the silty clay soil domain. For soil developed on basalts clay content does not increase with depth but remain fairly constant and fall within the silty clay soil domain. The presence of clays in soils tent to affects its structure, as aggregation creates intra-aggregate and inter-aggregate pore space, thereby changing flow paths for water, gases, solutes and pollutants (Fell 2000).

According to the Atterberg limits soils with a high value PI tend to be clay, those with a lower PI tend to be silt, and those with a PI of 0 tend to have little or no silt or clay. According to the soil plasticity soils developed on rhyolite, trachyte and basalt are moderately plastic. This moderate plasticity can be attributed to the presence of clay and silt proportions in the soils.

From the activity one can predict the dominant clay type present in a soil sample. High activity signifies large volume change when wetted and high shrinkage when dried. Soils with high activity are very reactive chemically. Normally the activity of clay is between 0.75 and 1.25 , and in this range clay is called normal clay. It is assumed that the plasticity index is approximately equal to the clay fraction $(\mathrm{A}=1)$. When $\mathrm{A}$ is $<0.75$, it is considered inactive, when it is $>1.25$, it is considered active. Consequently, soils developed on rhyolite and basalt has clays which are inactive, while clays from soils developed on trachyte are active clays. The consistency index permits us to situate the soil within the plastic limit gauge and is a function of the ratio of the difference between the liquid limit and the water content on the Plasticity index. The CI of all the soil samples developed on rhyolite, trachyte and basalt have values $>1$ indicating they are plastic in nature. The presence of plastic soils is evident of high clay content in these soils.

According to the liquidity index table, all the soil samples are $<0$ and therefore have a solid or semi-solid state. Following the plasticity index table, all soil samples fall in the less plastic domain.

The high water content in trachyte can be attributed to their high activity. This therefore signifies large volume change when wetted and large shrinkage when dried. These soils are therefore very reactive chemically. The high density of the grains in on soils developed on basalt can be attributed to the presence of ferromagnesian minerals in the rock like olivine and pyroxene which releases $\mathrm{Fe}$ which react to form $\mathrm{Fe}$-complexes in the soil. According to Mc Roberts and Nixon (1976), the typical void ratios might be 0.3 for a dense, well graded granular soil and 1.5 for soft clay. Therefore the soils identified in the study area are indicative of a well graded granular soil. Due to the high void ratio, the soils tend to be porous and retain water, thus increasing the weight of the soil after heavy rains rendering it unstable.

\subsection{Textural soil classification}

Soil classification separates soils into classes or groups each having similar characteristics and potentially similar behaviour. The United State Department of Agriculture (USDA) textural classification triangular chart (Fig.3) places the soils into the silty loam soil for sample on rhyolite, while samples on trachyte and on basalt are sandy loam soils. Further textural classification according to the Agricultural classification system, with the gradation limits of textural soil groups, classifies the soils as belonging to Group 1D (loams and silt loam) with a silt loam texture for soils on rhyolite Group 1C (sandy loams), with a fine sandy loam texture for samples on trachyte and Group 1D (loam and silt loams) with a loam texture for samples on basalt.

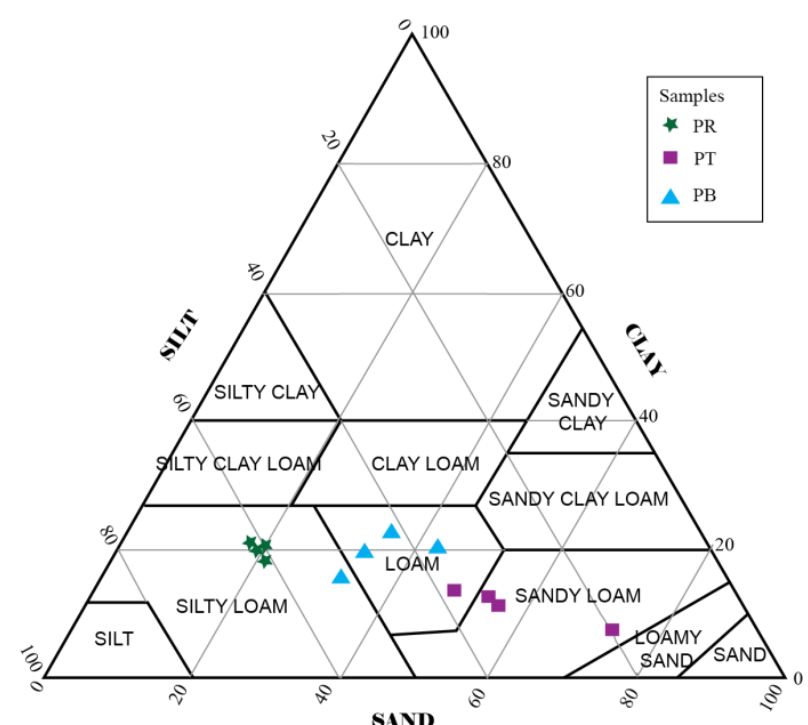

Fig. 3: United States Department of Agriculture Textural Classification Triangular Chart.

The textural classification of the soils characterizes them as silty loam, loam and sandy loam (Fig.4). This soil is mostly composed of sand, silt and clay at a ratio of $40-40-20 \%$ by weight respectively. These soils tend to hold water enough water and drain well and are very good for agricultural purposes (Brown 2007).

According to the cassagrand's plasticity chart of the USCS, these soils are medium to high plasticity silts (Fig.4). This property confers the soils the property to retain water and increase the bulk density of the soil. The silty nature of the soils is due to minerals in the rocks such as quartz and alkalis feldspars.

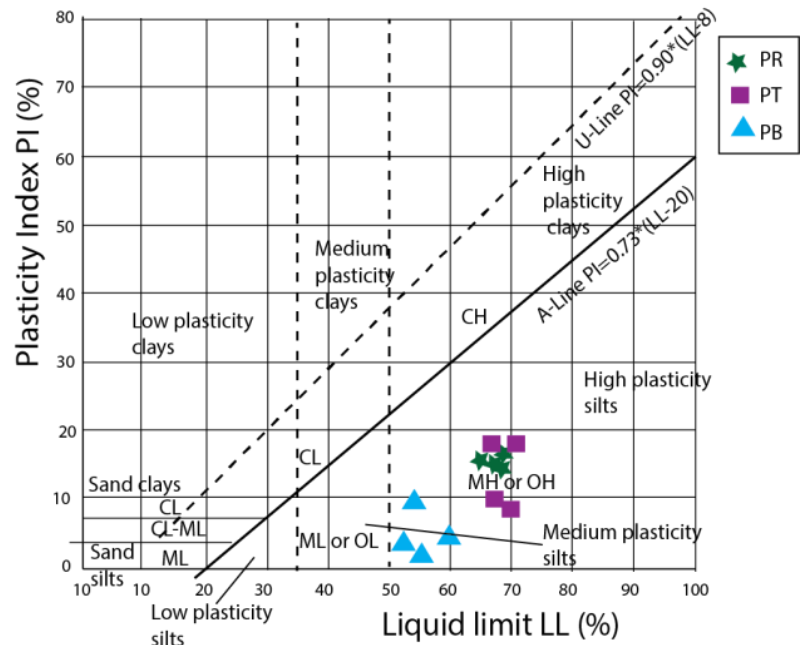

Fig. 4: Casagrand's Plasticity Chart for Soil Samples on the Bamenda Mountain (Holtz And Kovacs 1981). 


\section{Conclusion}

Weathering indices indicate intense leaching in silica and alkaline and alkaline earth elements, with an advance to extreme chemical weathering in this environment. The main soil formation process here is ferralitisation. The concentration of $\mathrm{Al}_{2} \mathrm{O}_{3}$ and $\mathrm{Fe}_{2} \mathrm{O}_{3}$ are the highest in all the soil profiles. Generally, incompatible trace elements are more enriched in the soil phases than compatible and major elements, with $\mathrm{Mn}$ (5.7) being the most enriched element in the soil.

Grain size distribution show the abundance of silt $(43 \%)$ and sand (39\%) particle and are well graded. Soils developed on rhyolite have a very high methylene blue value compared to soil developed on basalt and trachyte. Consistency and plasticity values indicate these soils developed on the rock types are plastic to moderately plastic. Texturally, these soils are silty loam, loam and sandy loam soils. Porosity, void index and water content are high for the soil samples. The cohesion for the soil samples is low $<0.5$ bar and angle of internal friction is high for some samples than the natural slope.

\section{Acknowledgements}

This research did not receive any specific grant from funding agencies in the public, commercial, or not-for-profit sectors. Special thanks to all independent reviewers who improved the quality of this manuscript.

\section{References}

[1] Babechuk, MG., Widdowson, M., Kamber, BS (2014) Quantifying chemical weathering intensity and trace element release from two contrasting basalt profiles, Deccan Traps, India. Chemical Geology 363, 56-75. https://doi.org/10.1016/j.chemgeo.2013.10.027.

[2] Bayiga, EC., Bitom, D., Ndjigui, P.D., Bilong, P (2011) Mineralogical and geochemical characterization of weathering products of amphibolites at SW Eséka (Northern border of the Nyong unit, SW Cameroon) Journal of Geology and Mining Research Vol. 3(10), pp. 281-293.

[3] Berger, A., Janots, E., Gnos, E., Frei, R., Bernier, F (2014) Rare earth element mineralogy and geochemistry in a laterite profile from Madagascar. Appl. Geochem. 41:218-228. https://doi.org/10.1016/j.apgeochem.2013.12.013.

[4] Birkeland PW (1984) Soils and geomorphology: New York, Oxford University Press, 372 p.

[5] Brikeland PW (1999) Soil and Geomorphology. Oxford University Press, New York. 174 p.

[6] Braun JJ, Pagel M, Herbillon A, Rosin (1993) Mobilisation and distribution of REEs and thorium in syenitic lateritic profile: a mass balance study. Geochim. Cosmochim. Acta, 57: 4419-4434. https://doi.org/10.1016/0016-7037(93)90492-F

[7] Brown M (2007) Crustal melting and melt extraction, ascent and emplacement in orogensis: mechanisms and consequences. Journal of the Geological Society of London 164, 709-730. https://doi.org/10.1144/0016-76492006-171.

[8] Boynton (1984) Geochemistry of the rare earth elements: meteorite studies. In: Henderson P (ed), Rare earth element geochemistry. Elsevier, pp. 63-114. https://doi.org/10.1016/B978-0-444-421487.50008-3.

[9] Caspari T, Bäumler, Norbu C, Tshering K, Baillie I (2006) Geochemical investigation of soils developed in different lithologies in Bhutan, Eastern Himalayas. Geoderma 136: 436-458. https://doi.org/10.1016/j.geoderma.2006.04.017.

[10] Chunying C, Fangbai L, Chengshuai L, Jianfeng G, Hui T and Manjia C (2016) Fractionation characteristics of rare earth elements (REEs) linked with secondary $\mathrm{Fe}, \mathrm{Mn}$, and $\mathrm{Al}$ minerals in soils. Acta Geochim (2016) 35(4):329-339. Acta Geochim (2016) 35(4):329-339.

[11] Cox R, Lowe DR, Cullers RL (1995) the influence of sediment recycling and basement composition on evolution of mud rock chemistry in the southwestern United States. Geochimica et Cosmochimica Acta 59: 2919-2940. https://doi.org/10.1016/00167037(95)00185-9.
[12] Dequencey O, Chabaux F, Clauer N, Sigmarsson O, Liewig N, Leprun JC (2002) Chemical mobilizations in laterites: evidence from trace elements and238 U-234 U-230 Th disequilibria. Geochimica et Cosmochimica Acta 66, 1210-1997.

[13] Di Figlia MG, Bellanca A, Neri R, Stefansson A (2007) Chemical weathering of volcanic rocks at the island of Pantelleria, Italy: information from soil profile and soil solution investigations. Chemical Geology 246, 1-18. https://doi.org/10.1016/j.chemgeo.2007.07.025.

[14] Fell R (2000) Landslide risk management concepts and guidelines. Australian Geomechanics Society, Sub-committee on landslide risk management, $69 \mathrm{p}$.

[15] Feng JL (2010) Behaviour of rare earth elements and yttrium in ferromanganese concretions, gibbsite spots, and surrounding terra rossa over dolomite during chemical weathering. Chemical Geology 271, 112-132. https://doi.org/10.1016/j.chemgeo.2010.01.003.

[16] Fouateu YR, Ghogomu RT, Penaye J, Ekodeck GE, Stendal H, Colin F (2006) .Nickel and cobalt distribution in the laterites of the Lomié region, South-East Cameroon. J. Afr. Earth Sci. 45, 33-47. https://doi.org/10.1016/j.jafrearsci.2006.01.003.

[17] Galan E, Fernandez-Caliani JC, Miras A, Aparicio P, Marquez MG (2007) Residence and fractionation of rare earth elements during kaolinization of alkaline peraluminous granites in NW Spain. Clay Miner 42:341-352. https://doi.org/10.1180/claymin.2007.042.3.07.

[18] Harnois L (1988) The CIW index: a new chemical Index of weathering. Sedimentary Geology 55, 319-322. https://doi.org/10.1016/0037-0738(88)90137-6.

[19] Herbillon AJ (1988) Chemical estimation of weatherable minerals presents in the diagnostic horizons of low activity clay soils. In: proceedings of the $8^{\text {th }}$ International Soil Classification Workshop: Classification, Characterisation and Utilisation of Oxisols (eds F.H. Beinroth, M.N Camargo \& H. Eswaran), pp. 39-48. EMBRAPA, Rio de Janeiro.

[20] Holtz and Kovacs (1981) Introduction to Geotechnical Engineering Holtz Kovacs \& Sheahan 2nd Edition solutions manual.

[21] Huang L, Hong J, Tan WF, Hu HQ, Liu F (2008) Characteristics of micromorphology and element distribution of iron-manganese cutans in typical soils of subtropical China. Geoderma 146:40-47. https://doi.org/10.1016/j.geoderma.2008.05.007.

[22] Kabata-Pendias A (2001) Traces Elements in Soils and Plants, third ed CRC Press. LLc, USA, pp. 413.

[23] Kamgang P, Njonfang E, Chazot G, Tchoua FM (2007) Géochimie et géochronologie des laves felsiques des monts Bamenda (ligne volcanique du Cameroun). C.R. Géoscience, 339, 659-666. https://doi.org/10.1016/j.crte.2007.07.011

[24] Kamgang P, Chazot G, Njonfang E, Tchoua FM (2008) Geochemistry and geochronology of mafic rocks from Bamenda Mountains (Cameroon): Source composition and crustal contamination along the Cameroon Volcanic Line. C.R. Géoscience, 340, 850-857. https://doi.org/10.1016/j.crte.2008.08.008.

[25] Kamgang K, BV, Onana VL, Ndome EPE, Parisot JC, Ekodeck GE (2009) Behaviour of REE and mass balance calculations in a lateritic profile over chlorite schists in South Cameroon. Chemie der Erde, 69: 61-73. https://doi.org/10.1016/j.chemer.2008.08.003.

[26] Kamgang P, Njonfang E, Nono A, Gountie D, Tchoua F (2010) Petrogenesis of a silicic magma system: Geochemical evidence from Bamenda Mountains, NW Cameroon, Cameroon Volcanic Line. $\quad 341, \quad 12, \quad$ p645-654 https://doi.org/10.1016/j.jafrearsci.2010.03.008.

[27] Lambiv Dzemua G, Mees F, Stoops G, Van Ranst E (2011) Micromorphology, mineralogy and geochemistry of lateritic weathering over serpentinite in South-East Cameroon. Journal of African Earth Sciences 60, 38-48. https://doi.org/10.1016/j.jafrearsci.2011.01.011

[28] Laveuf C and Cornu S (2009) A review on the potentiality of rare earth elements to trace pedogenetic processes. Geoderma 154:1-12. https://doi.org/10.1016/j.geoderma.2009.10.002.

[29] Leybourne MI, Goodfellow WD, Boyle DR (2000) Hydrogeochemical, isotopic and rare earth element geochemistry of acid-sulphate and acid-sulphate- chloride geothermal systems from Yellowstone National Park, Wyoming, USA. Geochim. Cosmochim. Acta 61, 695-723.

[30] Lopez-Galindo A, Viseras C, Cerezo P (2007) Compositional, technical and safety specifications of clays to be used as pharmaceutical and cosmetic products. Applied Clay Science 36, 51-63. https://doi.org/10.1016/j.clay.2006.06.016.

[31] Marker A, De Oliveira JJ (1990) the formation of rare earth element scavenger minerals in weathering products derived from alkaline rocks of SE-Bahia, Brazil. Chem Geol 84:373-374. https://doi.org/10.1016/0009-2541(90)90271-8. 
[32] Marsh JS, (1991). REE fractionation and Ce anomalies in weathered Karoo doleritie [J]: Chem. Geol., v. 90, p. 189-194. https://doi.org/10.1016/0009-2541(91)90099-D.

[33] McRoberts EC and Nixon JF (1976) A theory of Soil Sedimentation. Canadian Geotechnical Journal, 13: 294-3 10.

[34] Ndjigui PD, Bilong P, Bitom D, Dia A (2008) Mobilization and redistribution of major and trace elements in two weathering profiles developed on serpentink 98ites in the Lomié ultramafic complex, SouthEast Cameroon. Journal of African Earth Science, 50, 305-328. https://doi.org/10.1016/j.jafrearsci.2007.10.006.

[35] Ndjigui PD, Bilong P, Bitom D (2009) Negative cerium anomalies in the saprolite zone of serpentinite lateritic profiles in the Lomie ultramafic complex, South East Ckmmmmmmmmlllameroon. Journal of African Earth Sciences 53, 59-69. https://doi.org/10.1016/j.jafrearsci.2008.09.002

[36] Ndjigui PD, Badinane MFB, Nyeck B, Nandjip HPK, Bilong P (2013) Mineralogical and geochemical features of the coarse saprolite developed on orthogneiss in the SW of Yaoundé, South Cameroon, Journal of African Earth Sciences 79 (2013) 125-142. https://doi.org/10.1016/j.jafrearsci.2012.11.008

[37] Nesbitt HW, Markovics G, Price RC (1980) Chemical processes affecting alkalis and alkaline earths during continental weathering. Geochimica et Cosmochimica Acta 44(11): 16591666. https://doi.org/10.1016/0016-7037(80)90218-5.

[38] Nesbitt YW and Young GM (1982) Early Proterozoic climates and plate motions inferred from major element chemistry of lutites: $\mathrm{Na}$ ture, 299, 715-717. https://doi.org/10.1038/299715a0.

[39] Nestbitt HW and Young GM (1989) Formation and diagenesis of weathering profiles. J. Geol. 97, 129-147. https://doi.org/10.1086/629290.

[40] Nesbitt HW and Wilson RE (1992) Recent chemical weathering of basalts. American Journal of Science 292: 740-777. https://doi.org/10.2475/ajs.292.10.740.

[41] Ngapgue F, Madjadoumbaye J, Nouanga P, Amadou T, Tamo TT (2012) Modelling of frictional and cohesive resistances of Bafoussam (Cameroon) soils. Vol. 17 [2012], Bund. D. 10p.

[42] Öhlander B and Romer RL (1996) Zircon ages of granites occurring along the Central Swedish Gravity Low. GFF 118, 217-225. https://doi.org/10.1080/11035899609546257.

[43] Ohnuki T, Ozaki T, Kozai N, Nankawa T, Sakamoto F, Sakai T, Suzuki Y, Francis AJ (2008) Concurrent transformation of Ce (III) and formation of biogenic manganese oxides. Chemical Geology 253, 23-29. https://doi.org/10.1016/j.chemgeo.2008.03.013.

[44] Price JR, Velbel MA (2003) Chemical weathering indices applied to weathering profiles developed on heterogenous felsic metamorphic parent rocks. Chemical Geology 202, 397-416. https://doi.org/10.1016/j.chemgeo.2002.11.001.

[45] Rahn KA and Mc Cafrfrey RJ (1979) Compositional differences between Arctic aerosol and snow. Nature, 280, 479-480. https://doi.org/10.1038/280479a0.

[46] Retallack, G.J., (2001). Soils of the past: an introduction to paleopedology. Oxford Blackwell Science Ltd, Oxford https://doi.org/10.1002/9780470698716.

[47] Robitaille, V. and Tremblay, D (1997) Mécanique des sols (théorie et pratique). Modulo éd. Quebec-Canada, 652p.

[48] Ruxton BP (1968) Measures of the degree of chemical weathering of rocks. Journal of Geology. 76, 518-527. https://doi.org/10.1086/627357.

[49] Schroeder PA, Melear ND, West LT, Hamilton DA (2000) Metagabbro weathering in the Georgia Piedmont, USA: implications for global silicate weathering rates. Chemical Geology 163: 235-245. https://doi.org/10.1016/S0009-2541(99)00129-1.

[50] Sanematsu K, Kon Y, Imai A, Watanabe K, Watanabe Y (2013) Geochemical and mineralogical characteristics of ion-adsorption type REE mineralization in Phuket, Thailand. Miner Depos 48:437451. https://doi.org/10.1007/s00126-011-0380-5.

[51] Singh B, Sherman DM, Gilkes RJ, Wells MA, Mosselmans JFW (2002) Incorporation of $\mathrm{Cr}, \mathrm{Mn}$ and $\mathrm{Ni}$ into goethite $(\mathrm{a}-\mathrm{FeOOH})$ : mechanism from extended X-ray absorption fine structure spectros$\begin{array}{llll}\text { copy. } & \text { Clay } & \text { 636-649. }\end{array}$ https://doi.org/10.1180/000985502374066.

[52] Terence A (2011) ed. (2003). Powder sampling and particle size determination (1st ed.). Amsterdam: Elsevier. ISBN 978-0-44451564-3.

[53] Tematio P, Fritsch E, Hodson ME, Lucas Y, Bitom D, Bilong P (2009) Mineral and geochemical characterization of a leptic aluandic soil and a thapto aluandic-ferralsol developed on trachytes in Mount Bambouto (Cameroon volcanic line). Geoderma, 152, 314323. https://doi.org/10.1016/j.geoderma.2009.05.029.
[54] Tematio P, Kombou NA, Kengni L, Nguetnkam JP, Kamgang KV (2012) Mineral and geochemical characterization of the weathering mantle derived from norites in Kekem (West Cameroon): evaluation of the related mineralization. International Research Journal of Geology and Mining (IRJGM) (2276-6618) Vol. 2(8) pp. 230-242.

[55] Tijani MN, Okunola AO, Abimbola AF (2006) Lithogenic concentration of trace metals in soils and saprolites over crystalline basement rock: Journal of African Earth Sciences; Vol 46, Issue 5, pp 472-438.

[56] Tsopjio JSP, Tematio P, Wilson MA, Yemefack M (2011) Andosolization of Soils on a Strombolian Cone at Mount Bambouto, Cameroon. Open Journal of Soil Science, 2011, 1, 97-105 doi 10.4236/ojss.

[57] Veronica EM, Cheo ES, Christopher MA, Elisha MS (2013) Mineralogy and geochemistry of soils developed along the slopes of $\mathrm{Mt}$. Cameroon, West Africa. Journal of African Earth Sciences 81. 8293. https://doi.org/10.1016/j.jafrearsci.2013.01.008.

[58] Wouatong ASL, Yerima BPK, Yongue Fouateu R, Mvondo Ze A, Ekodeck GE (2013) The Origin of Etch Pits Recorded on Residual Grain Surfaces from Kaolinized Granitic Rocks West Region Cameroon. Earth Science Research; Vol. 2, No. 2.

[59] Wouatong ASL, Medjo Eko R, Nankam MA, Kamgang Kabeyene Beyala V, Ekodeck GE (2014) Mineralogy, Geochemistry and Geotechnical Characteristics of Magha Landslides in the Bambouto Caldera, West Cameroon. Journal of Civil Engineering and Science. Vol. 3 Iss. 1, PP. 36-49.

[60] Yusoff ZM, Ngwenya BT, Parsons I (2013) Mobility and fractionation of REEs during deep weathering of geochemically contrasting granites in a tropical setting, Malaysia. Chem Geol 349-350:71-86. https://doi.org/10.1016/j.chemgeo.2013.04.016. 